\title{
REVISIONISME STUDI AL-QUR'AN DI BARAT: PENDEKATAN, TIPOLOGI, DAN RELASI PENGETAHUAN-KUASA DALAM KAJIAN DAVID S. POWERS TENTANG AYAT-AYAT WARIS
}

\author{
Wardani \\ UIN Antasari Banjarmasin \\ mwardanibjm@gmail.com
}

Diterima 26-07-2020 | Direview 03-08-2020 | Diterbitkan 15-12-2020

Abstract:

The commonly accepted assumption among Muslims is that the Islamic law of inheritance known as 'ilm al-farä idh represents what correctly understood from the Qur'an. This article is intended to study David S. Powers' study of the transformation of the so-called proto-Islamic law of inheritance accepted from the Prophet into this science. The study will be focused on his approach to this issue, his stand within oriental study of the Qur'an, and his study viewed from poscolonial perspective. Employing synthesized typology of orientalists' stand in studying Islam, and Edward Said's perspective of the so-called "intellectual powers", in this article, I argue that Powers' study of the issue represents revisionist's stand of Islam and the Qur an, applying synthesized approaches of literary and historical criticism. But, his analysis belongs the Western radical analysis of influence of Roman law on the Islamic law and in the context of West-East opposision, reflects Western people's superiority against Eastern's (Muslim community) inferiority in understanding their own scripture, the Qur’àn.

Keywords: Heirs, Islamic Law of Inherintance, Kalālah, Proto Islamic Law

\begin{abstract}
Abstrak
Anggapan yang diterima umumnya di kalangan kaum muslimin adalah babwa bukum Islam tentang waris yang dikenal dengan 'ilm al-faräïh merepresentasikan apa yang dipahami secara benar dari al-Qur'an. Artikel ini dimaksudkan untuk mengkaji studi David S. Powers tentang perubahan dari apa yang disebut bukum-purwa (awal) Islam tentang waris yang diterima dari Nabi menjadi ilmu ini. Dengan menerapkan tipologi yang disintesiskan tentang posisi orientalis dalam mengkaji Islam, dan sudut pandang Edward Said tentang "kuasa intelektual", dalam artikel ini, penulis ingin menyatakan bahwa kajian Power tentang isu itu merepresentasikan pendirian seorang revisionis terhadap Islam dan al-Qur'an, dengan menerapkan pendekatan
\end{abstract}


sisntesis antara kritik literer dan kritik sejarah. Akan tetapi, analisis yang dikemukakannya berasal dari analisis Barat yang radikal berkaitan dengan pengaruh hukum Romawi terhadap hukum Islam dan dalam konteks oposisi Barat-Timur, merefleksikan superioritas orang Barat terhadap inferioritas Timur (masyarakat Muslim) dalam memahami kitab suci mereka sendiri, alQurian.

Kata Kunci : Abli Waris, Hukum Islam tentang Waris, Kalālah, ProtoIslamic Law (Hukum Purwa Islam)

\section{Pendahuluan}

Gabriel Said Reynolds pernah mengatakan "the golden age of Qur anic studies has arrived" (abad keemasan kajian-kajian al-Qur'an telah tiba). ${ }^{1}$ Ketika karya Powers tersebut terbit pada 2008, pada tahun yang sama telah terbit, The Qur 'ān in Its Historical Context, ed. Gabriel Said Reynolds yang memuat tulisantulisan orintalis hasil konferensi pada 2005 di Universitas Notre Dame. Konferensi ini membahas hubungan antara al-Qur`an dengan late antiquity (fase akhir masa klasik yang mendahului atau menyertai masa turunnya al-Qur`an) ${ }^{2}$ dari perspektif retrospective. ${ }^{3}$

Wacana dominan seperti inilah yang menyertai juga dorongan Powers untuk menulis karyanya tentang perubahan hukum awal Islam (proto-Islamic law) yang secara otentik diterima dari Nabi menjadi 'ilm al-farā $i d h$ yang rumit dengan hitungan matematis seperti kita lihat. Powers adalah seorang orientalis yang kini menjadi professor di Universitas Cornell, Amerika Serikat. Ia adalah orientalis yang kini banyak menulis sejumlah karya, tidak hanya artikel, melainkan juga beberapa buku yang sebagian berisi kritik tajam atas beberapa doktrin dalam Islam. Bahkan, sebagian dari tulisan memicu kontroversi karena kritik yang tidak tanggung-tanggung terhadap semisal persoalan kenabian melalui karya Mubammad is Not the Father of Any of Your Men: the Making of the

\footnotetext{
1Sebagaimana dikutp dalam Yusuf Rahman, “Tren Kajian Al-Qur'an Di Dunia Barat," Jurnal Studia Insania 1, no. 1 (2013): 2.

${ }^{2}$ Yang dimaksud dengan "late antiquity" adalah periodisasi yang dikemukakan oleh para sejarawan untuk menyebut masa transisi antara classical antiquity hingga abad pertengahan. Secara umumnya, masa transisi ini terhitung dari akhir masa krisis Empirium Romawi di abad ke-3 M (235-284) hingga penaklukan oleh Islam di pertengahan abad ke-7 $\mathrm{M}$ (en.m.wikipedia.org/wiki/Late-antiquity (17 Juli 2020).

${ }^{3}$ Lihat pada Gabriel Said Reynolds, "Introduction: Qur'anic studies and its controversies," dalam The Qur' an in its Historical Context (London; New York: Routledge, 2007), 17.
} 
Last Prophet..$^{4}$ Sebelumnya, pada 2008, ia menerbitkan sebuah buku yang berasal disertasi di Universitas Princeton pada 1979 yang kemudian direvisinya melalui kajian-kajian yang lanjut dengan pendekatan sosio-historis terhadap kewarisan dalam Islam. David S. Powers dalam kajian tentang pembentuk hukum waris dalam Islam mencoba masuk ke dasar-dasar normatif pembacaan tafsir alQur'an tentang itu dan meletakkannya ke dalam analisis konteks historisnya.

Kajian-kajian tentang kritik David S. Powers terhadap perubahan hukum awal Islam tentang kewarisan menjadi ilmu farā ìdh telah dilakukan. Kajian Niswatul Hidayati, "Rekonstruksi Hukum Waris Islam: Makna Kalalah David S. Power", 5 hanya memfokuskan kajian pada penafsiran ulang Powers terhadap makna kalālah dalam al-Qur`an (Q.s. 4: 12). Kajian ini meski menelaah reinterpretasi sebagai bagian dari argumentasi Powers bagi klaim terhadap adanya manipulasi penafsiran klasik yang menyertai perubahan hukum waris itu, kajian ini tentu hanya berhenti pada wilayah argumentasi (metodologi), namun tidak melihatnya dari skema lebih luas tentang posisi keseluruhan kajiannya, termasuk metodologi yang diterapkannya, dalam konteks pendekatan dan kepentingan orientalis terhadap kajian al-Qur'an secara khusus maupun Islam secara umum.

Sebuah review terhadap buku ini ditulis Michael Bonner dari Universitas Michigan, Ann Arbor. Menurut Bonner, kajian Powers mampu menengahi dua kecendungan dalam kajian hadits, antara perspektif Barat, seperti Joseph Schacht, yang sangat pesimis terhadap otentisitas hadīts Nabi di satu sisi, dan perspektif muslim umum, baik ulama klasik seperti al-Syāfi' maupun ulama modern seperti Muhammad Mushthafa al-A'zhamī. Kajian Powers, menurutnya, mampu menjawab tantangan tesis yang dilontarkan sebelumnya oleh Michael Cook yang mengatakan "pilihan antara Schacht dan Syāfi'ī tidak ada metodologi posisi tengah". ${ }^{6}$ Kajian ini terfokus pada posisi tawaran Powers dalam konteks perdebatan otentitas hadīts Nabi, tidak sama sekali menyoroti posisi tawar pemikirannya dalam konteks kajian al-Qur`an.

${ }^{4}$ Lihat M. Z. Qadafy, "Kontroversi Islam Revisionis: David S. Powers, Zayd Ibn H\$\} \$ a rithah dan Tertutupnya Pintu Kenabian,” Nun 4, no. 1 (2018): 45-81.

${ }^{5}$ Niswatul Hidayati, "Rekontruksi Hukum Waris Islam: Makna Kalalah David S. Power," Muslim Heritage 2, no. 1 (2017): 177-198.

'Lihat Michael Bonner, "Reviews," International Journal of Middle East Studies 26, no. 2 (1994): 343. 
Sebuah essai review terhadap karya Carl W. Ernst, How to Read the Qur an, yang berisi survei perkembangan kajian-kajian al-Qur'an akhir-akhirnya yang ditulis oleh Travis Zadeh, "Quranic Studies and Literary Turn", malah tidak menyebutkan karya-karya Powers yang dalam karyanya ini, dan beberapa lain (Zayd), menerapkan pendekatan sastra. ${ }^{7}$

Kajian terhadap pemikiran Powers juga dikemukakan oleh Mu'ammar Zayn Qadafy, meski hanya tentang persoalan kenabian melalui bukunya, Mubammad is Not the Father of Any of Your Men, namun artikelnya ini memiliki kesimpulan yang bisa berlaku umum, yaitu tentang posisi tawaran revisionisnya dalam memahami Islam dari perspektif orientalis. Kesimpulan bahwa Powers dengan menerapkan genealogi kenabian, ia secara apatis terhadap sumber tradisional Islam. Model analisis old orientalisme, seperti dengan sejarah keselamatan (salvation history) dalam tradisi Yahudi juga digunakan dalam analisisnya terhadap persoalan kenabian. ${ }^{8}$

Kajian yang arahnya pada aspek pendekatan, namun tidak menganalisis dalam skema trend pembacaan sebagai orientalis pada Powers ini, adalah kajian Safruddin Edi Wibowo, "Kritik Sejarah dan Literasi terhadap Hukum Waris Islam dalam Pandangan David S. Powers". ${ }^{9}$ Kajian ini tidak menganalisis pemikiran Powers dalam konteks kecenderungan pembacaannya terhadap Islam atau terhadap al-Qur an.

Kajian-kajian ini tidak mengkaji dari dua perspektif yang sebenarnya saling terkait. Pertama, perspektif epistemologis yang terkait dengan sumber, metode, dan pendekatan. Kedua, perspektif post-kolonial untuk melihat kaitan antara poisis kajian ketimurannya dengan konteks relasi pengetahuan dan kuasa. Perspektif ini diperlukan dalam konteks kajian yang lebih komprehensif; tidak hanya terkait dengan analisis dari "dalam" (metode dan pendekatan), melainkan juga analisis dari "luar" (konteks ideologis).

Kajian-kajian tentang hukum waris yang selama ini dilakukan adalah sebagai berikut. Pertama, kajian W. Robertson Smith dalam Kinship and Marriage in Early Arabia (1903) yang menyatakan bahwa hukum waris Islam dipengaruhi oleh hukum adat kabilah Arab pra-Islam, yaitu tentang pembagian-pembagian

${ }^{7}$ Lihat lebih lanjut Travis Zadeh, "Quranic studies and the literary turn," Journal of American Oriental Society 135, no. 2 (2015): 329-342.

${ }^{8}$ Lihat, lebih lanjutnya, Qadafy, "Kontroversi Islam Revisionis," 45-81.

"Safrudin Edi Wibowo, "Kritik Sejarah dan Literasi terhadap Hukum Waris Islam dalam Pandangan David S. Powers,” Jurnal Islamica 4, no. 2 (2013): 306-18. 
(fardh) dan 'ashabah. Kajian Smith menekankan karakter kesukuan, nomadis, bangsa Arab pra-Islam, seperti diyah dan rampasan perang. ${ }^{10}$

Kedua, kajian W. Marçais dalam Des Parents et Alliés Successibles en Droit Musulman dengan "teori pelapisan" (superimposition theory) bahwa hukum Islam dilapiskan di atas hukum adat dan para ahli hukum kemudian memadukan kedua elemen yang berbeda itu untuk membentuk hukum waris. ${ }^{11}$ Menurut Marçais, Muhammad melapiskan suatu rezim pengganti yang berpihak kepada perempuan di atas praktik-praktik waris yang sebelumnya male oriented dalam adat tribal Arab. ${ }^{12}$ Marçais kemudian mengingkari teori dalam sebuah suratnya ke G. H. Bousquet, namun teori pelapisan ternyata tetap dikembangkan oleh tokoh-tokoh sesudahnya.

Ketiga, kajian G. H. Bousquet dalam Les Successions Agnatiques Mitigées dengan tetap menerima teori Marçais, tapi memberikan dasar metodologi berbeda, yaitu dengan menganalisis singkat (walaupun dikritik Powers karena masih superfisial) ayat-ayat waris dalam al-Qur'an yang menurut merupakan data yang otentik dibanding data sejarah Arab pra-Islam (karena ia menolak dualitas suksesi Nabi antara di Mekkah dan di Madinah). ${ }^{13}$

Teori Smith, Marçais, dan Bousquet dibantah oleh David S. Powers dengan temuan R. Brunschving ketika meneliti kumpulan hadits awal yang menyatakan bahwa 'ashabah Arab pra-Islam tidak identik dengan 'ashabah dalam Islam. Pertimbangan Powers dalam menerima temuan Brunschving adalah: [1] pertimbangan historis bahwa Strabo, ketika menggambarkan Yaman pada abad pertama Masehi, menunjukkan bahwa kontrol atas warisan dan penggunaan jabatan politik diatur atas prinsip senioritas; [2] bahwa berdasarkan riwayat Ibn 'Abbās adalah hal yang lazim bagi orang-orang Arab Jahiliah untuk memberikan warisan kepada anggota suku yag paling tua; [3] pertimbangan linguistik bahwa bentuk konsonantal (tanpa harakat) kata 'ushbah yang sama dengan kata 'ashabah sering muncul dalam puisi-puisi Arab pra-Islam dan selalu berarti sekelompok pria bersuku sama; dan [4] pertimbangan etnografis bahwa Chelhod dalam kajiannya tentang hukum orang-orang Badui mencatat bahwa

${ }^{10}$ David S. Powers, Studies in Qur'ān and Hadīth: The Transformation of the Islamic Law of Inheritance (Berkeley: University of California Press, 1986), 18.

${ }^{11}$ Powers, 109-10.

${ }^{12}$ Powers, 19.

13Powers, 20. 
prinsip senioritas mengatur peralihan warisan akibat kematian. ${ }^{14}$ Jadi, berbeda dengan konsep 'ashabah dalam Islam yang didasarkan atas keturunan langsung, 'ashabah dalam adat tribal Arab pra-Islam didasarkan atas prinsip senioritas.

Keempat, N. J. Coulson dalam Succession in the Muslim Family juga mengakui validitas "teori pelapisan" itu. Namun, teori Coulson juga dikritik oleh Powers. Bahkan, Powers memperkirakan bahwa Coulson tidak mengetahui teori R. Brunschving, setidaknya, tidak pernah menyebutnya. ${ }^{15}$ Powers mengkritik rumusan Coulson sebagai rumusan yang tidak dibekali oleh perangkat kritik yang cukup dan tidak ada bibliografi. Kekurangan dokumentasi, khususnya, justeru terdapat pada bagian di mana Coulson mengembangkan penjelasan-penjelasannya tentang asal-usul historisnya. ${ }^{16}$ Berbeda dengan Coulson, Schacht tampaknya menerima sebatas kepentingan mendukung tesisnya, back-projection, kemungkinan tesis R. Brunschving sambil merekomendasikan tesis itu tetap harus diuji. ${ }^{17}$

Teori pelapisan yang masih berkembang dan disepakati oleh mayoritas pakar sejarah hukum dan ingin direvisi Powers dalam kajiannya ini pada dasarnya adalah sebagai berikut:

Al-Qur'an menetapkan hak-hak waris antar-suami-istri dan para kerabat dekat perempuan dengan memberikan fardh warisan kepada mereka. Aturan-aturan itu dengan sendirinya bukan merupakan suatu sistem yang komplit, tetapi hanya modifikasi akan golongan ahli waris baru di atasnya. 'Ashabah, para ahli waris pra-Islam, masih mewarisi, tetapi sekarang hanya setelah warisan itu dibagikan kepada para ahli waris yang ditetapkan al-Qur'an, abl al-farā 'idh. Dua elemen heterogen

${ }^{14}$ Powers, 113-15.

${ }^{15}$ Powers, 116. Meski teori Coulson ditolak, beberapa penulis sejarah hukum Islam ada yang menerimanya, bahkan dengan perluasan. Lihat Mohammad Mustafa Ali Khan, Islamic Law of Inheritance: a New Approach (New Delhi: Kitab Bhavan, 1989).

16Powers, Studies in Qur'ān and Hadìth, 21. catatan kaki no.48.

${ }^{17}$ Scahcht mengatakan: "The possibility that some adage or other may even go back to the pre-Islamic period cannot be excluded a priori, but this must be positively proved - as has been done, so far, for one particular maxim (al-walā lil-kubr, concerning the transmission of the right of the patron, mawla , by inheritance) which reflects an archaic rule of agnatic succession." Joseph Schacht, An introduction to Islamic law, Repr. (Oxford: Clarendon Press, 1984), 40. 
itu, hukum adat tribal Arabia pra-Islam dan legislasi al-Qur'an, kemudian dileburkan menjadi satu membentuk 'ilm al-farā 'idh. ${ }^{18}$

Dengan menolak "teori pelapisan" dan menerima tesis R. Brunschving, David S. Powers memiliki pendirian berbeda dengan apa yang dipostulatkan oleh Barat, yaitu: (1) 'ashabah Arabia pra-Islam tidak identik dengan 'ashabah dalam hukum Islam; (2) hukum waris al-Qur'an sesungguhnya terdiri dari sistem waris yang benar-benar lengkap dan menyeluruh; (3) tujuan utama legislasi al-Qur'an adalah untuk mendefinisikan kembali urutan prioritas mewarisi berbagai kelas ahli waris, bukan memperluas hak waris kepada para wanita; dan (4) hukum waris al-Qur' an secara total menggantikan hukum adat Arabia pra-Islam, bukan sekedar melengkapi atau memodifikasi hukum adat itu. ${ }^{19}$ Akan tetapi, meski menerima tesis R. Brunschving, kajiannya itu bukanlah sebuah kajian yang komprehensif karena hanya mengajikan fakta-fakta dari hadits. Powers bertolak-di samping hadits-hadits-dari fakta al-Qur'an; memeriksa tafsiran yang berkembang sambil "mundur ke belakang" (memeriksa kembali/ ulang tafsiran-tafsiran itu) di mana terjadi legal-fiction (fiksi hukum) dan bagaimana proses peng-ayat-an (versification; bagaimana ayat-ayat tersebut dibentuk) terjadi. Ini yang membedakan kajian Powers dengan kajiankajian Barat di atas yang bertolak dari sejarah. Di samping telaah literer, Powers juga menerapkan analisis sejarah, suatu hal lain yang membedakan kajiannya dengan kajian Brunschving.

\section{Metode}

Artikel ini mengkaji interpretasi Powers terhadap ayat-ayat waris dalam kesimpulan besar (tesis) yang dikemukakannya berkaitan dengan perubahan hukum awal waris Islam yang otentik menjadi ilmu farā $i d h$ dari dua aspek; pertama, dari aspek epistemologi, yaitu unsur-unsur fundamental risetnya dari latar belakang, tesis, metode, pendekatan, dan argumentasi yang dikembangkan; kedua, dari aspek tipologi kajian Powers sebagai kajian orientalisme di Barat. Dalam konteks tipologi, artikel ini akan menerapkan pembacaan kritis dengan melihat relasi pengetahuan dan kuasa (knowledge and power). ${ }^{20}$ Salah satu ide yang

\footnotetext{
${ }^{18}$ Powers, Studies in Qur'ān and Hadìth, 21.

${ }^{19}$ Powers, 110.

${ }^{20}$ Azyumardi Azra, "Pengantar", dalam Ahmad Baso, Islam Pascakolonial: Perselingkuhan Agama, Kolonialisme, dan Liberalisme (Bandung: Mizan, 2005), 18-19. Tentang sejarah sosial yang
} 
dikembangkan dalam model analisis post-strukturalisme Michael Foucault adalah "genealogi kekuasaan", yaitu dengan "interogasi tak kenal lelah terhadap apa-apa yang dianggap alami, niscaya, atau tetap" 21 berkaitan dengan relasi pengetahuan-kuasa tersebut.

Teori yang digunakan dalam kajian ini adalah tipologi orientalis. Ada beberapa tipologi yang dikemukakan oleh para pengkaji, yang satu sama lain saling melengkapi. Pertama, tipologisasi Salim Kerboua yang melihat pergeseran kajian-kajian orientalisme yang melihat adanya tiga pergeseran orientalisme dilihat dari waktu, paradigma, sumber, objek yang dikaji, penggambaran tentang objek, dan agenda yang ingin diwujudkan.

\section{Tabel 1:}

Tipologi Kajian Orientalisme ${ }^{22}$

\begin{tabular}{|c|c|c|c|}
\hline Aspek & Orientalisme Awal & $\begin{array}{c}\text { Orientalisme } \\
\text { Amerika }\end{array}$ & Neo-orientalisme \\
\hline Standar waktu & Abad ke-18-19 M & $\begin{array}{l}\text { Masa perang } \\
\text { dingin/ pasca- } \\
\text { perang dingin } \\
(1945-1990-\text { an })\end{array}$ & $\begin{array}{l}\text { Sejak 1990-an, } \\
\text { khususnya sejak } 2001\end{array}$ \\
\hline Paradigma & $\begin{array}{l}\text { Paradigma kolonial/ } \\
\text { imperialisme }\end{array}$ & $\begin{array}{l}\text { Paradigma perang } \\
\text { dingin }\end{array}$ & $\begin{array}{l}\text { "Perang dengan } \\
\text { teror" yang bergeser } \\
\text { ke paradigma } \\
\text { "benturan } \\
\text { antarperadaban" }\end{array}$ \\
\hline Sumber & $\begin{array}{l}\text { Inggris dan Perancis } \\
\text { (filolog dan } \\
\text { seniman) }\end{array}$ & $\begin{array}{l}\text { Amerika (ilmuwan } \\
\text { sosial dan media, } \\
\text { lingkaran pro-Israel }\end{array}$ & $\begin{array}{l}\text { Neo-konservativisme } \\
\text { dan lingkaran pro- } \\
\text { Israel di Amerika } \\
\text { Serikat dan Eropa }\end{array}$ \\
\hline $\begin{array}{l}\text { Objek yang } \\
\text { dikonstruk }\end{array}$ & $\begin{array}{l}\text { Timur dan orang- } \\
\text { orangnya }\end{array}$ & $\begin{array}{l}\text {-Amerika Serikat } \\
\text {-Arab dan Muslim }\end{array}$ & $\begin{array}{l}\text {-Islam, dunia Islam, } \\
\text { dan Muslim } \\
\text {-Muslim di Barat }\end{array}$ \\
\hline $\begin{array}{l}\text { Ciri } \\
\text { penggambaran } \\
\text { objek yang }\end{array}$ & $\begin{array}{l}\text {-Pasif } \\
\text {-Inferior } \\
\text {-Terbelakang }\end{array}$ & $\begin{array}{l}\text {-Amerika Serikat: } \\
\text { adi-daya yang baik } \\
\text {-Timur: terbelakang }\end{array}$ & $\begin{array}{l}\text {-Ancaman bagi Israel } \\
\text { dan "Barat" }\end{array}$ \\
\hline
\end{tabular}

tidak kronologis, seperti yang ditulis Lombard, lihat Azyumardi Azra dan Idris Thaha, Historiografi Islam Kontemporer: Wacana, Aktualitas, dan Aktor Sejarah (Jakarta: Gramedia Pustaka Utama, 2002), 12-16.

${ }^{21}$ George Ritzer dan Douglas J. Goodman, Modern Sociological Theory terj. Alimandan (Jakarta: Kencana, 2003), 611-12.

${ }^{22}$ Salim Kerboua, "From Orientalism to neo-Orientalism: Early and contemporary constructions of Islam and the Muslim world," Intellectual Discourse 24, no. 1 (2016): 21. 


\begin{tabular}{llll} 
dikaji & & dan kekerasan & \\
\hline Agenda & -Dominasi & -Kepentingan geo- & -Pandangan dan \\
& -Kolonialisasi & strategik Amerika & kepentingan Israel \\
& Serikat & \\
& -Kepentingan & \\
& ekonomi & \\
& -Keamanan Israel
\end{tabular}

Tipologi ini tentu hanya melihat dari aspek kajian orientalisme terhadap Islam dan dunia Islam secara umum, sedangkan pergeserannya dalam konteks kajian-kajian al-Qur`an tidak jelas terlihat, meski hal ini berguna sebagai kerangka makro dilihat dari agenda besar yang mungkin juga berpengaruh besar terhadap kajian-kajian al-Qur`an.

Carl W. Ernst dan Richard C. Martin mencatat adanya fenomena postkolonial dalam kajian-kajian agama, termasuk Islam. Trend kajian post-kolonial tidak lagi mengaitkan dengan berbagai kepentingan ideologis seperti di atas, melainkan mengkaji Islam sebagai agama dari perspektif yang lebih simpatik. Memang, seperti dicatat oleh Ernst dan Martin, tidak mudah untuk memisahkan antara orientalisme dan studi kawasan di satu sisi, dengan studi agama di sisi lain. Ada keinginan kuat menjembatani dan mentrasformasikan dua tradisi keilmuan ini, orintalisme dan studi agama. Dari sini, Islam dilihat dari kerangka teoretis yang lebih baru, misal teori kritis dan kosmopolitanisme. ${ }^{23}$

Khusus dalam konteks kajian-kajian al-Qur`an, Yusuf menawarkan tiga model kajian orientalisme berdasarkan bagaimana orientalis memposisikan pengkaji berkaitan "teks" (al-Qur`an) yang dikajinya: (1) apa yang ada di balik teks (behind the text), yaitu memfokuskan kajian pada persoalan otentisitas alQur'an, seperti dengan pendekatan filologis, text criticism, dan form criticism sebagaimana menjadi fokus perhatian semisal Ignaz Goldziher (m. 1921), Theodor Noldeke (m. Edward Sell (m. 1932), dan Arthur Jeffery (m. 1959) (2) apa yang ada di hadapan teks (what is before/ in front of the text), yaitu tentang bagaimana al-Qur'an al-Qur`an telah dan selalu berpengaruh kepada para pembacanya, jadi tidak mempersoalkan otentisitasnya, seperti yang dilakukan dengan pendekatan sastra, seperti tampak dari The Literary Structures of Religious Meaning in the Qur'an ed. Issa J. Boullata, dan dari karya Angelika Neuwirth, A.

${ }^{23}$ Carl W. Ernst dan Richard C. Martin, Introduction: Toward a Post-Orientalist Approach to Islamic Religious Studies dalam Rethinking Islamic Studies, ed. Carl W. Ernst dan Richard C. Martin (Columbia: University of South Caroline Press, 2010), 2. 
H. Johns, A. M. Zahniser, Michael Sells, dan A. T. Welch. Di samping itu, kajian orientalisme juga bisa dibedakan menjadi dua tipe, yaitu "tradisionalis" yang masih berkutat pada persoalan klasik tentang asal-usul kitab suci alQur`an, seperti keterpengaruhan dengan tradisi Yahudi-Kristen dan "revisionis" yang telah merevisi tesis-tesis orientalis terdahulu. ${ }^{24}$

Dalam kajian ini, digunakan kerangka yang diterapkan oleh Salim Karboua dan Yusuf Rahman di atas dalam melihat tipologi orientalisme dan dilengkapi dengan aspek lain, yaitu posisi pengkaji dalam hubungannya dengan teks (al-Qur`an) dan pendekatan yang digunakan. Penulis juga akan melihat posisi Powers dalam konteks studi post-kolonial, khususnya melalui ide Edward Said tentang "kuasa intelektual".

Sumber utama kajian ini adalah karya Powers, Studies in Qur'ān and Hadith: The Transformation of the Islamic Law of Inberitance. Karya ini telah diterjemahkan dengan judul, Peraliban Kekayaan dan Politik Kekuasaan. ${ }^{25}$

\section{Pembahasan}

\section{Latar Belakang Intelektual ${ }^{26}$}

David Stephan Powers adalah guru besar dalam bidang hukum dan sejarah Islam. Ia lahir pada tanggal 23 Juli 1951 di Cleveland, Ohio. Ia menikah dengan Jane Levine Powers dan dikaruniai dua orang puteri dan seorang putera. Pendidikan tingkat B.A. diperolehnya di Yale University di bidang Near Eastern Languages and Literatures pada tahun 1973. Setelah itu, ia meneruskan pendidikan M.A. dan Ph.D. di Princeton University di bidang sejarah Islam dan selesai pada tahun 1979 .

Sekarang ia menjabat sebagai guru besar hukum dan sejarah Islam di Department of Near Eastern Studies di Cornell University. Di samping itu, ia juga menempati jabatan-jabatan penting, seperti: kordinator Comparative Muslim Societies Seminar (1989-sekarang), kepala Arabic and Islamic Studies Committee (1988-sekarang), pimpinan Hillel Faculty Board (1989-1990), Ketua Department of Near Eastren Studies (1993-1996), anggota Religious Studies Program Steering Committee (1993-1994), dan anggota Arts and Sciences Admissions Committee (1981-1983, 1986-1987).

\footnotetext{
${ }^{24}$ Rahman, “Tren Kajian Al-Qur'an di Dunia Barat,” 2.

${ }^{25}$ David S. Powers, Peralihan Kekayaan dan Politik Kekuasaan (Yogyakarta: LKiS, 2001).).

${ }^{26}$ Data tentang hidup, karya, dan karir David S. Powers merujuk kepada http: www.arts.cornell.edu/nes/faculty/powers.htmldiakses pada 12 Juli, 2020 dan http: www.arts.cornell.edu/jwst/powers.html diakses pada tanggal 12 Juli 2020.
} 
Karya-karyanya dalam bentuk paper yang dipresentasikan di forumforum ilmiah adalah sebagai berikut:

1. "Familial Politics in $14^{\text {th }}$ Century Algeria", seminar on "Women and Children in Muslim Society," Haifa University, 27 Mei 1997.

2. "Immoral Conduct and the Problem of Judicial Legitimacy," seminar on "The Public Sphere in Muslim Society," Van Leer Institute, 17 April 1997.

3. "The Dynamics of Legal Continuity," workshop on "The Dynamics of Legal Change in Muslim Societies," The Hebrew University, 19 Maret 1997.

4. "The Art of Judicial Opinion: On Tawlij in $14^{\text {th }}$-Century Tunis," Forum in memory of Professor Baneth, Hebrew University, 26 Februari 1997.

5. "The Art of the Judicial Opinion in Islamic Law," Yale University, September 1993.

6. "Conficting Conceptions of Property in Fifteenth Century Morocco," Washington University Conference on Law and Praxis, St. Louis, Mei 1992.

7. "Law and Language," Annual Meeting of the American Oriental Society, Boston, Maret 1992.

8. "Waqf and Hadith," Fourth International Colloquium on Hadith, Amsterdam, 26 Agustus 1991.

9. "The Maliki Family Endowment: ca. 900-1500," International Colloquium: Normes Juridiques et Pratiques Sociales dans le Monde Musulman, Paris, Januari 1991.

10. "On Judicial Review in Islamic Law," SOAS conference on Islamic Public Law, London, 30 Juni 1990.

11. "On Judicial Review in Islamic Law," Annual Meeting of the American Oriental Society Atlanta, Georgia, 26 Maret 1990.

12. "Fatwas as Sources for Legal and Social History," SSRC Conference on the Making of a Fatwa, Granada, Spanyol, Januari 1990.

Karya-karyanya dalam bentuk buku adalah sebagai berikut:

1. Law, Society, and Culture in the Magbrib, 1300-1500 (Cambridge University Press, 2002), terbaru.

2. Studies in Qur'ān and Hadith: The Formation of the Islamic Law of Inheritance (University of California Press, 1986) dan diterjemahkan ke bahasa 
Indoensia oleh Arif Maftuhin dengan judul Peralihan Kekayaan dan Politik. Kekuasaan (Yogyakarta: LKiS, 2001).

3. Islamic Legal Interpretation: Muffīs and their Fatwās, ed. M. Khalid Masud, Brinkley Messick, and David S. Powers (Harvard University Press, 1996).

4. The History of al-Tabari, Volume XXIV: The Caliphates of Sulayman, Umar II, and Yazid. State University of New York Press, 1989 (terjemahan beserta anotasi).

5. Mubammad is Not the Father of Any of Your Men (Philadelpia: University of Pennsilvania Press, 2009).

6. Zayd (Philadelpia: University of Pennsilvania Press, 2014).

\section{Artikel-artikel:}

1. "Colonialism, Orientalism, and Legal History: The Attack on Muslim Family Endowments in Algeria and India," Comparative Studies in Society and History 31 (1989): 535-571.

2. "The Will of Sa'd bin Abī Waqqās: A Reassessment". Dalam Studia Islamica, 58 (1983), pp. 33-53.

3. "Fatwās as Sources for Legal and Social History: A Dispute over Endowment Revenues from Fourteenth-century Fez,", in Al-Qantara, Vol.XI, 1990, pp. 295-341. Dimuat kembali dalam Howard M. Federspeil (general editor), An Anthology of Islamic Studies, Volume II. Montreal: Indoensia-Canada Islamic Higher Education Project, 1996, h. $198-233$.

4. "On Judicial Review in Islamic Law," Law and Society Review, 26, 2 (1992), 315-341.

5. "On Bequests in Early Islam," Journal of Near Eastern Studies 48 (1989): 185-200.

6. "A Court Case from Fourteenth-Century North Africa", Journal of the American Oriental Socities 110: 2 (1990), pp. 229-254.

7. "Revenues of Public Endowments in Sixteenth-Century Jerusalem," Archivum Ottomanicum 9 (1984): 163-202.

8. "On the Abrogation of the Bequest Verses," Arabica 29 (1982): 246295.

9. "The Islamic Law of Inheritance, Reconsidered: A New Reading of Q.4: 12b,” Studia Islamica 55 (1982): 61-94. 


\section{Review Buku:}

1. Review: Chibli Mallat, The Renewal of Islamic Law: Muhammad Baqer as-Sadr, Najaf and the Shii International. American Historical Riview (October, 1995), 1270-72.

2. Review: John Burton, Sources of Islamic Law. Journal of the Royal Asiatic Society: 933-34.

3. Review: L. Rosen, The Anthropology of Justice: Law as Culture in Islamic Society. Journal of the American Oriental Society 111.4 (1991): 790-91.

4. Review: John Burton (ed.), Abu cUbaid al-Qasim b. Sallam's K. alnasikh wa-l-mansukh. Speculum 65 (1990): 933-934.

5. Review: P. Crone, Roman, provincial, and Islamic law. Journal of Semitic Studies 35 (1999): 326-330.

6. Review: N.J. Coulson and Abdelwadoud Yehia, Studien zum Islamischen Recht. The Muslim World 77 (1987): 139.

7. Review: M. Ayyoub, The Qur'an and Its Interpreters. The Muslim World 75 (1985): 51-52.

8. Review: J. Esposito (ed.), Islam and Development. NYU Journal of International dan Politics 15 (1982): 476-486.

\section{Latar Belakang Kajian: Kritik atas Tesis Orientalis dan Anggapan Para Ulama Klasik}

Selama ini, hukum Islam tentang kewarisan memperoleh tanggapan dan klaim yang berbeda. Pertama, klaim dalam tradisi Islam klasik bahwa hukum waris ('ilm al-fara $' i d h$ ) adalah bagian ajaran Islam yang karena bersumber dari al-Qur'an dan hadits wajib dipelajari atau diajarkan. ${ }^{27}$ Dalam statemen yang lebih tegas, 'ilm al-farā'idh adalah representasi wahyu dan kehendak Tuhan, sebuah otentisitas Islam. Klaim tentang 'ilm al-farā ìdh

\footnotetext{
${ }^{27}$ Teks hadits menyatakan;

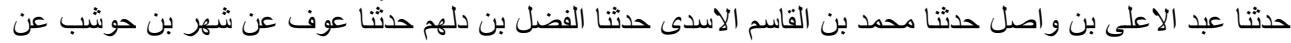

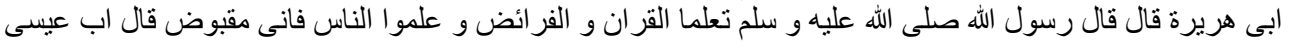

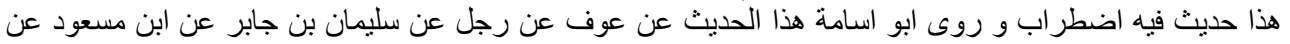

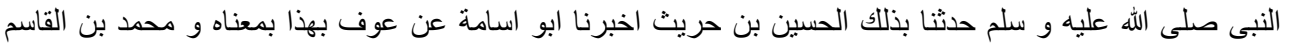

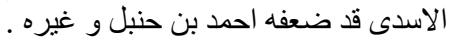

Sunan at-Tirmidzī, "Kitāb al-Farā idh 'an Rasūl Allāh", hadīts nomor 2017. Dikutip dari "CDROM Mawsū'at al-hadīts asy-syarīf, edisi ke-2, 2000, hak cipta Syarikat al-Barāmij alIslāmiyyah al-Dawliyyah [Global Islamic Sofware Company], 1991-1997).
} 
sebagai pemahaman murni seluruhnya dari al-Qur'an menyebabkan setiap muslim tidak boleh mengingkarinya. Klaim tersebut, tentu saja, adalah a-bistoris yang melupakan proses kesejarahan-bahwa ada penanganan intelektual, pelibatan model suatu pemahaman yang dikondisikan oleh kondisi-kondisi sejarah, sosial, dan politis dari karakternya sebagai "produk sejarah"-hukum waris tersebut. Keadaan ini persis yang seperti yang sering dikhawatirkan oleh Mohammed Arkoun tentang "sakralisasi pemikiran-pemikiran keagamaan" (taqd̄̄s al-afkēar ad-dinniyyah). Jadi, klaim ini berbasis dari asumsi keliru bahwa alQur'an adalah satu-satunya faktor dalam proses legislasi Islam, dalam hal ini hukum waris. Ini sesungguhnya klaim otentisitas (mana pemahaman yang paling mewakili ajaran al-Qur'an) sehingga muncul "Islam qur'ani" (Qur'anic Islam $)^{28}$ di satu sisi, atau sense of historisity itu tadi yang hilang di kalangan muslim sehingga fiqh diidentikkan dengan agama di sisi lain. Padahal, al-Qur'an yang telah ditafsirkan di tangan para mufassir justeru terjadi perbedaan tafsir yang mengesankan bahwa ide al-Qur'an kontradiktif. “Mengapa al-Qur'an bertentangan dengan dirinya sendiri?" atau "Mengapa al-Qur'an berseberangan dengan fiqh?", tanya Powers. ${ }^{29}$ Di kalangan mayoritas muslim, fiqh identik dengan agama atau identik dengan wahyu (lihat bantahan al-Ashmawī dalam Ushül asy-Syari'ah [versi terjemah Nalar Kritis Syariab]).

Kedua, David S. Powers mengritik dalam tesis Joseph Schacht tentang formasi hukum Islam: (a) hukum Islam dikatakan belum ada pada masa Nabi Muhammad (abad ke-1 H), melainkan setelah penunjukkan $q \bar{a} d h \bar{\imath}$ generasi awal pada masa Umayyah (abad $2 \mathrm{H} / 7 \mathrm{M}$ ); (b) tentang fakta Qur'an: Aturan-aturan tertentu, termasuk tentang hukum waris hanya menyangkut hal-hal elementer saja, tidak sampai pada tahap pembentukan, bahkan praktik awal menyimpang dari teks eksplisit al-Qur'an; (c) tentang fakta hadits, yaitu tentang "tradisi yang hidup" (living tradition) yang berisi kesepakatan anonim suatu generasi ulama atas praktik-praktik legal abad $2 \mathrm{H}$ dengan sandaran berkesinambungan, semula

\footnotetext{
${ }^{28}$ Meminjam istilah yang digunakan 'Abdallah M. al-Husayn al-'Amiri, "At-Thūfi's Refutation of Traditional Muslim Juristic Sources of Law and His View on the Priority of Regard for Human Welfare as the Highest Legal Sources or Principle" (Canada: McGill University, 1993). dan diterjemahkan oleh Abdul Basir, Dekonstruksi Sumber Hukum Islam: Pemikiran Hukum Najm ad-Dīn Thufi (Jakarta: Penerbit Gaya Media Pratama, 2004), 75. Istilah yang kurang lebih sama yang muncul sebagai judul buku seperti "Islam Otentik", "Islam Substantif", dan "Islam Sejati".

${ }^{29}$ Powers, Studies in Qur'ān and Hadìth, 93.
} 
di kalangan ulama pada abad ke-1 $\mathrm{H}$, lalu di kalangan Sahabat Nabi, hingga dibakukan pada masa Nabi. Tradisi keilmuan orientalis di Barat justeru bergerak kebalikannya dengan memberlakukan perangkat analisis kesejarahan in the strict sense dalam proses legislasi itu dengan melupakan peran al-Qur'an. Kesimpulan yang mengejutkan kalangan fuqabā dan mufassir Muslim dan menimbulkan pengaruh yang besar antara pro dan kontra dalam kesarjanaan Barat atas tesis Joseph Schacht tentang projecting back (mengembalikan asal-usul hadits dan juga hukum Islam ke perkembangan sejarah belakangan) dalam The Origins of Muhammadan Jurisprudence dan An Introduction to Islamic Law. Joseph Schacht mengatakan:

Originally the consensus of the scholars was anonymous, that is to say, it was the average opinion the representatives of a school that counted, and not the individual doctrines of the most prominent scholars. The living tradition of the ancient schools maintained this essentially anonymous character well into the second half of the second century of Islam. Nevertheless, the idea of continuity inherent in the concept of sunna, the idealized practice, together with the need to create some kind of theoritical justification for what so far had been an instinctive reliance on the opinions of the majority, led, from the first decedes of the second century onwards, to the living tradition being projected backwards and to its being ascribed to some of the great figures of the past. ${ }^{30}$

Schacht sebenarnya menguatkan tesis pendahulunya, Ignaz Goldziher, dalam Mubammadanische Studien. Tesis penting Goldziher adalah bahwa meski ia mengakui koleksi hadits tertulis dalam bentuk lembaran-lembaran terpisah (shubuf), ia tetap menyakini bahwa proses pencatatan hadits baru dimulai pada abad ke-2 H. ${ }^{31}$ Schacht yang meski menguatkan tesis itu, studinya terfokus pada hadits-hadits hukum dan berupaya merekonstruksi bahwa jusriprudensi Islam yang ditandai dengan munculnya hadits dalam kitab-kitab hukum. Tesis Schacht mengalami respon beragam dan memiliki pengaruh yang kuat dalam

${ }^{30}$ Schacht, An introduction to Islamic law, 31.

${ }^{31}$ Charles J. Adams, "Islamic Religious Tradition", dalam Leonard Binder (ed.), The Study of the Middle East: Research and Scholarship in the Humanities and the Social Sciences (New York: John Wiley \& Sons Inc., 1976), 67. 
kajian hadits berikut yang pada dasarnya dapat dikalsifikasikan menjadi dua arus pemikiran.

Pertama, eksponen Schacht dengan tesis yang diperbaiki atau dimodifikasi sedikit, seperti S. Vesey-Fitzgeral yang mengakui adanya hukumhukum dalam "kisah-kisah palsu" yang berasal dari Nabi Muhammad dan N. J. Coulson yang mengakui ketidakotentikan sebagian besar hadits hukum yang dinisbatkan kepada Nabi Muhammad dan menganggapnya hanya sebagai hasil dari projecting-back.32 Namun, Coulson dengan sambil menerima tesis itu mengkritisi putusnya kesinambungan antara al-Qur'an dengan perkembangan hukum Islam dalam uraian Schacht. Meski David S. Powers tidak menyebut keterpengaruhan Fazlur Rahman, namun Charles J. Adams mengkategorikan Rahman dalam Islamic Methodology in History ${ }^{33}$ sebagai eksponen Schacht ketika merekonstruksi perkembangan hukum Islam dan hubungan proses ini dengan perkembangan literatur hadits. ${ }^{34}$

Kedua, kalangan revisionis, dalam hal ini adalah sebagai berikut.

1) Nabia Abbott dalam karyanya, Studies in Arabic Literary Papyri terdiri 2 volume yang diterbitkan pada tahun 1967. Tujuan Abbott sebenarnya tidak memfokuskan kajiannya pada otentisitas hadits sebagaimana Goldziher atau pada hadits-hadits hukum sebagaimana Schacht. Namun, penelitiannya terhadap papirus awal membuktikan adanya ketertarikan para sahabat Nabi terhadap hadits pada abad pertama, adanya koleksi hadits dalam bentuk tulisan pada fase-fase paling awal dan kesinambungan pentransmisinya hingga abad ke-3 $\mathrm{H}$, dan ilmu hadits bukanlahsebagaiman asumsi umum - hanya bagian dari akibat perkembangan hukum dalam masyarakat (seperti tesis Schacht).

2) Fuat Sezgin dalam Geschichte des Arabishen Schriptums volume 1 yang diterbitkan bersamaan dengan tahun Abbot menerbitkan karyanya. Karyanya dirancang sebagai perluasan, koreksi, dan pembaruan data dalam karya Brockelmann, Geschichte des Arabishen Literatur. Dalam diskusinya tentang hadits, Sezgin tidak hanya mendukung, melainkan melampaui kesimpulan-kesimpulan yang dicapai oleh Abbott. Dalam volume 1

${ }^{32}$ Powers, Peralihan Kekayaan dan Politik Kekuasaan, 3.

${ }^{33}$ Lihat bukunya, Fazlur Rahman, Islamic Methodology in History (New Delhi: Adam Publishers \& Distributors, 1994). Buku ini telah diterjemahkan ke bahasa Indonesia oleh Anas Mahyuddin, Fąlurrabman Terj. Anas Mabyuddin Membuka Pintu Ijtihad (Bandung: Penerbit PUSTAKA, 1884).

${ }^{34}$ Adams, “Islamic Religious Tradition”, 66. 
karyanya, Sezgin mengemukakan kritik tajam terhadap rekonstruksi Goldziher tentang tadwin al-hadits dalam volume 2 Mubammadanische Studien. Sezgin, sebagaimana Abbott, juga berkesimpulan bahwa proses perekaman hadits telah dimulai sejak masa hidup Nabi Muhammad dan berlanjut tanpa putus sampai munculnya karya-karya besar koleksi hadits pada abad ke-3 H/ 9 M. ${ }^{35}$

3) Muhammad Mushthafā al-A'zham̄̄ dalam disertasi doktorya di Cambridge University, Studies in Early Hadith Literature (1978). ${ }^{36}$ A'zhamī berkesimpulan sama dengan Abbott dan Sezgin tentang perekaman hadits dan mempertanyakan, sebagaimana Coulson, tentang peran legislasi alQur'an. Di samping itu, ia juga meragukan identifikasi Schacht pada kata "fitnab" sebagai perang sipil (civil war) menyusul kematian Walīd bin Yazīd. Ia juga mengkirik kegagalan Schacht dalam mamahami teks-teks Arab tertentu, mengutip statemen keluar dari konteks, berargumen berdasarkan kasus-kasus pengecualian, dan membuat generalisasi hanya berdasarkan contoh terbatas. ${ }^{37}$

Ketiga, "posisi tengah" G. H. A. Juynboll dalam karyanya, Muslim Tradition: Studies in Chronology, Provenance, and Authorship of Early Haditth. Pada bagian pengantar buku ini, ia menjelaskan latar belakang mengapa ia melakukan penelitian itu. Pada pertengahan tahun 1960-an, ia menulis disertasi The Authenticity of of the Tradition Literature: Discussions in Modern Egypt.38 Ia mengaku bahwa ia tidak terlibat dalam perdebatan, baik antar tokoh Timur maupun antara tokoh Timur dan Barat. Juynboll juga mengaku bahwa ia tidak hanya dipengaruhi oleh Goldziher dan Schacht, melainkan oleh tokoh muslim modern. "If two points of view could differ so widely, how could anyone even attempt to

${ }^{35}$ Adams, 66-67. Powers, Studies in Qur'ān and Hadīth, 6.

${ }^{36}$ Disertasi ini juga diterbitkan dalam bahasa Arab, Muhammad Mushthafā alA'zhamī, "Dirāsah fi al-Hadìts an-Nabawīy wa Tārīkh Tadwinnih" (Beirut: Dār al-Fikr, 1973). dan diterjemahkan ke bahasa Indonesia oleh Ali Mustafa Ya'kub, Kodifikasi Hadis Nabi (Jakarta: Pustaka Firdaus, 1994). Karya lain di mana ia mengkritik tesis Schacht adalah Manbaj an-Naqd 'ind al-Muhadditsin.

${ }^{37}$ Powers, Studies in Qur'ān and Hadìth, 6.

Mesir.

${ }^{38}$ Karya ini telah diterjemahkan ke bahasa Indonesia dengan judul Kontroversi Hadis di 
bring them into harmony?", ${ }^{39}$ tanyanya. Pada tahun 1976, Juynboll melakukan penelitian dan membuktikan adanya para $q \bar{a} d h \bar{\imath}$ muslim generasi awal memain peranan penting dalam penyebaran hadits (ini juga sasaran kajian Schacht dalam membangun tesisnya). Di sini, ia mulai menemukan titik di mana dua konsep yang berbeda bisa dipertemukan. Meski mengakui bahwa sertelah ini ia tidak akan mengatakan dirinya terpengaruh dengan salah sisi dari dua tradisi berbeda itu dan ia ingin merujuk ke sumber-sumber awal tanpa ingin membandingkan temuannya dengan Timur atau Barat sampai semuanya selesai, Juynboll sangat terpengaruh dengan teori "projecting back" atau "back-projection" dan teori "common link" Schacht. "However much I admire Schacht's Origins-I have in particular benefited from his theories that 'isnād-isnād have a tendency to grow backwards' and his 'common link theory'-because of its countless cross-references it also makes heary reading and its style seems to rub many readers, western and Muslim, up the wrong way." "40 Dengan latar belakang seperti itu, Juynboll mengajukan tiga persoalan pokok: (1) Dari mana suatu hadits tertentu berasal?; (2) Dalam waktu (kondisi) apa suatu hadits tertentu muncul?; dan (3) Siapa saja yang bertanggung jawab dalam peredaran hadits tertentu?. Dengan mengkaji kronologi munculnya hadits pada fase awal (bab 1), peran para $q \bar{a} d h \bar{\imath}$ dalam penyebaran hadits (bab 2), penyebaran hadits "man kadzaba" dalam literaturliteratur hadits (bab 3), penulisan kitab-kitab rijāl dan penilaian atas keterpercayaan kitab-kitab tersebut dalam menilai $r \bar{a} w \bar{\imath}$ (bab 4), dan evolusi tarjamah [biografi $r \bar{a} w \boldsymbol{l}$ ], Juynboll berkesimpulan bahwa ia tidak menolak semua kemungkinan bahwa perkataan dan/ atau aktivitas Nabi mungkin, setidaknya sebagiannya, telah diriwayatkan oleh seorang sahabatnya atau lebih. Akan tetapi, Juynboll masih skeptis apakah kita akan bisa membuktikan untuk menghilangkan bayang-bayang keraguan itu bahwa apa yang kita sebut sebagai "hadits Nabi yang shahīh" memang benar-benar mengandung pengertian seperti itu. Keraguan yang ia maksud terakhir adalah bahwa kita bisa membuktikan bahwa suatu perkataan/ perbuatan mungkin dikatakan/ dilakukan oleh Nabi dengan hanya merujuk ke koleksi-koleksi hadits (hukum atau tidak), tapi sungguh kita tidak menemukan suatu metode yang tepat untuk membuktikan kebenarannya dengan suatu kepastian yang tidak diperdebatkan lagi tentang historisitas perujukan/ penisbatan (with incontrovertible certainity the

${ }^{39}$ Gautier H.A. Juynboll, Muslim tradition: studies in chronology, provenance, and authorship of early hadīth (Cambridge: Cambridge University Press, 1983), 1.

${ }^{40}$ Juynboll, 3. 
bistorisity of the ascription) seperti itu kepada Nabi, kecuali dalam kasus kecil. ${ }^{41}$ Dengan menerima kemungkinan bahwa hadits memang berasal dari Nabi (seperti keyakinan tokoh muslim), meski dengan keraguan, Juynboll juga menerima tesis Schacht tentang perkembangan laporan-laporan formal hadits yang baru berkembang antara 670-700 M.42 Pada masa ini, kaum muslimin, menurutnya, mengembangkan standarisasi kritik hadits melalui karya-karya biografis yang tidak seluruhnya bisa dipercaya. Dalam uraiannya tentang penilaian terhadap kritik hadis yang diterapkan di kalangan muslimin (bab 4) dengan 'keraguan sehat' (healthy scepticism) seperti itu, ia menilai penggunaan Tabd ī $\bar{b}$ at-Tabdī $\bar{l} b$ yang memuat nama-nama, penilaian kredibilitas, dsb., untuk menilai mubadditsūn dua setengah abad pertama. Ia menemukan, misalnya, hingga batas "kebetulan-kebetulan" tertentu informasi sejarah yang asli tentang nama-nama tertentu yang mungkin disaring dari tarjamah-tarjamah yang tak terhitung banyaknya tentang $r \bar{a} w \bar{l}-r \bar{a} w \bar{l}$ majb $\bar{u} l$ (yang tidak dikenal). Ia juga menemukan bukti tak terbantah bahwa figur-figur kunci dalam transmisi hadits, seperti az-Zuhrī̄, menjadi pengumpul nama-nama rāwī yang terlibat dalam transmisi itu dan nama umumnya digunakan atau disalahgunakan oleh mereka itu atau dengan cara lain oleh para pemalsu hadits. ${ }^{43}$ Jadi, dengan "posisi tengah" (meski lebih cenderung ke teori Barat), ia menerima kemungkinan otentisitas hadits Nabi dan adanya periwayatan awal. Namun, standar kritik dan pelaporan formal di mana literatur-liateratur hadits dan kritiknya mulai ditulis yang bukan tidak mungkin terjadi 'anomali' adalah perkembangan belakangan.

Debat tentang hadits adalah relevan dikemukakan di sini karena rekonstruksi tokoh-tokoh di atas atas perkembangan awalnya berimplikasi terhadap perkembangan awal legislasi Islam, apalagi tesis Schacht yang menjadi titik tolak pro dan kontra tersebut di atas berbasis pada hadits-hadits hukum dalam koleksi-koleksi belakangan setelah Nabi.

Kajian Timur yang tetap penting dalam konteks perkembangan awal hukum Islam, namun tidak menggaung seperti halnya al-A'zhamī dalam kesarjanaan Barat dan jarang mereka sebut, termasuk David S. Powers sendiri, adalah The Early Development of Islam Jurisprudence oleh Ahmed Hasan. ${ }^{44}$

\footnotetext{
${ }^{41}$ Juynboll, 71.

${ }^{42}$ Powers, Studies in Qur'ān and Hadìth, 7.

43Juynboll, Muslim tradition, 159-60.

${ }^{44}$ Hassan dengan bertolak dari kritiknya terhadap Schacht berkesimpulan bahwa kandungan jurisprudensi Islam didasarkan atas al-Qur'an dan sunnah Nabi di masa yang paling
} 
Ketegangan yang dihadapi oleh Powers sesungguhnya adalah tipikal ketegangan pendekatan normatif dan historis. Pendekatan normatif yang diterapkan oleh tradisi Islam terhadap hukum Islam mengasumsikan otentisitas hukum Islam, dalam hal ini hukum waris, sebagai representasi murni wahyu. Sedangkan, pendekatan kesejarahan dalam pengertian umumnya menarik konsep yang lahir dalam tradisi Islam seperti itu ke akar-akar historisnya. Antara taqdīs dan [reduksi pada batas tertentu] historisasi, ada wilayah yang tak terkompromikan. Powers bertolak dari keadaan 'anomalos' seperti itu.

\section{Tesis dan Teori}

Hipotesis yang dibuktikan oleh David S. Powers adalah sebagai berikut. Pertama, bahwa masyarakat muslim saat ini sebenarnya tidak memiliki pembacaan dan pemahaman yang tepat atas beberapa ayat al-Qur'an dan hadits atau sistem waris yang diterima oleh Muhammad, karena sesudah wafatnya Nabi, beberapa orang tertentu telah memanipulasi teks al-Qur'an dalam upaya untuk mengubah makna-makna ayat terkait dengan waris.

Kedua, legislasi Islam sudah dimulai sejak turunnya al-Qur'an, sehingga usaha apa pun untuk melacak asal-usul hukum Islam semestinya mengambil al-Qur'an sebagi titik-awal (kritik atas Schacht), meski tidak juga dalam arti yang dipahami dalam tradisi Islam. ${ }^{45}$

Tesis Schacht ini telah menimbulkan tanggapan dari sejumlah kalangan revisionis, yaitu (a) S. Vesey-Fitzgerald, (b) N. J. Coulson yang menegaskan fakta peran al-Qur'an dalam pembentukan hukum adalah mata rantai yang diputus oleh Schacht dalam kesinambungan hukum; (c) G. H. A. Juynboll yang meragukan terhadap tesis Schacht tentang keberadaan isnād baru pada abad ke2 H dengan merujuk kata 'fitnah' pada Ibn Sīrīn; (d) Nabia Abbott melalui kajiannya terhadap tafsir dan hadits melalui papirus awal menunjukkan bahwa hadits sudah ditransmisikan pada abad ke-1 $\mathrm{H}$, adanya mata rantai antarrawi, dan adanya peningkatan literartur hadits abad ke-2-3 H bukan karena

awal, meski fakta itu tidak menafikan fakta lain bahwa perkembangan literatur-literatur di bidang ini berkembang dalam praktik dan administrasi priode Umayyah. Hassan juga mendiskusikan evolusi sejarah prinsip-prinsip dasar jurisprudensi Islam, yaitu al-Qur'an, sunnah, qiy $\bar{a} s$, dan $i j m \bar{a}$ '. Prinsip-prinsip tersebut telah diterapkan oleh ahli hukum Islam generasi paling awal. Pada bagian terakhir buku ini, dijelaskan pembentukan aliran-aliran fiqh dan kontribusi asy-Syāfi''̄ dalam jusrisprudensi Islam. Ahmed Hasan, The Early Development of Islamic Jurisprudence (India: Adam Publishers \& Distributors, 1994), vi.

${ }^{45}$ Powers, Studies in Qur'ān and Hadīth, ix. 
pemalsuan matn hadits; (e) Fuat Sezgin yang menelaah atas literatur-literatur Islam menunjukkan bahwa periwayatan hadits sudah ada pada masa Nabi secara berkesinambungan hingga abad ke-3 H; dan (f) Muhammad Mushthafā al-A'zhamī yang menegaskan tiga hal, yaitu memperkuat kritik Coulson atas pengabaian Scachat terhadap legislasi al-Qur'an, memperkuat kritik Juynboll tentang $i s n \bar{a} d$, dan kritik pengutipan ayat yang keluar dari konteks dan cara menarik generalisasi.

Kedua, kritik David S. Powers atas 'anomali' dalam nalar fuqahā' dan mufassir klasik bahwa 'ilm al-farā $i d h$ adalah hukum yang sudah merepresentasi kehendak Tuhan dengan melalui proses pembakuan oleh suatu model manipulasi pembacaan ( $q i r \bar{a} \bar{a} t)$, pemenggalan, atau penafsiran ayat dalam kondisi sosio-historis dan politik tertentu.

Kritik yang dilontarkannya pada prinsipnya terdiri dari dua point. Pertama, kajian-kajian terdahulu dianggap reduksionis, karena pengabaian terhadap peran al-Qur'an dalam proses legislasi. Kedua, kritiknya terhadap penyamaan antara jurisprudensi dan hukum positif oleh Schacht.

Tesis atau kesimpulan besar yang ingin dibangunnya adalah sebagai berikut. Pertama, ada kesinambungan dalam perkembangan hukum waris sejak Nabi hingga masa-masa berikut, jadi ada dasar normatif (merevisi tesis Schacht dan memperkuat tesis Coulson, Abbot, Sezgin, dan A'zhamī). Kedua, telah terjadi 'manipulasi' penafsiran ayat-ayat tentang waris (legal-fiction) dari pemahaman awal hukum masa Rasul (proto Islamic law, hukum purwa-Islam). Dalam hal ini, ia ingin merevisi tesis kalangan revisionis terdahulu, Azami dkk.

Kerangka teori (theoritical frame-work) yang diterapkan adalah sebagai berikut. Powers mengatakan sebagai berikut:

Thesis to be presented here doubly revisionist. On the one hand I shall argue that the law of inheritance developed in a continous manner, albeit with several early shifts of direction, from the time of the Prophet onwards. In this respect, my conclusions corroborate those of Coulson, Abbott, Sergin, and Azami.46

(Tesis yang disajikan di sini merevisi dua pandangan sekaligus. Di satu sisi, saya akan membuktikan bahwa hukum waris berkembang dalam suatu proses berkesinambungan, selainnya beberapa pergeseran arah pada awalnya, dari zaman Nabi ke masa-masa berikutnya. Dalam hal ini,

46Powers, 8. 
kesimpulan saya memperkuat kesimpulan-kesimpulan Coulson, Abbott, Sezgin, dan Azami).

Meski bergerak dari dua arah (teks dan sejarah), kajian Powers, professor sejarah dan hukum Islam, ini sebenarnya menitik-beratkan pada sisi historisitas hukum waris itu, yaitu bagaimana pemahaman awal tentang waris diterima oleh Nabi Muhammad kemudian berkembang menjadi ilm al-farā $i d$. Problem ini adalah problem tentang mana yang asal dan berubah, problem otentisitas. Historisitas tersebut dikaji dalam bingkai "kontinuitas dan perubahan" (continuity and change) dalam teori sejarah.. Aspek (normativitas) ini tetap bertahan. Akan tetapi, meski memiliki akar-akar normatif yang sama, tapi transformasi proto Islamic law ke 'ilm al-farā'id bukanlah tanpa perubahan, tapi justeru ditandai oleh pergeseran pemahaman ayat dan hadits dalam konteks sosio-politis tertentu, jadi telah terjadi perubahan (change).

Teori yang diterapkannya adalah kontinuitas dan perubahan (continuity and change). Menurutnya, dalam proses historis perubahan dari hukum awal (proto Islamic law) hingga menjadi 'ilm al-fara 'idh, ada unsur-unsur yang bertahan dan tetap berkseinambungan, yaitu legislasi al-Qur'an dan hadits-hadits, khususnya tentang wasiat dan waris, namun juga terjadi perubahan, yaitu karena kondisi sosio-politis dan pergeseran pemahaman agama, penafsiran terhadap sumber normatif mengalami perubahan, bahkan dimanipulasi.

\section{Metode dan Pendekatan Powers}

Penelitian ini menerapkan metode sintesis (gabungan), karena sifat datanya yang berupa data naskah/ teks/ dokumen dan data sejarah, antara kritik literer dan kritik sejarah. Pertama, kritik literer/ sastra (literary criticism) yang secara intensif diterapkan khususnya pada bagian pertama kajiannya (tentang proto Islamic law), ${ }^{47}$ yaitu kritik terhadap pemahaman atau penafsiran yang sebenarnya merupakan variant sekunder ${ }^{48}$ (dalam pembacaan,' qirā ' $\bar{a} t$ ', sintaksis, dan makna sejumlah kata) terhadap ayat-ayat dan hadits-hadits tentang waris yang berkembang dalam tradisi tafsir klasik, seperti tafsīr ath-

${ }^{47}$ Powers, 25-137.

${ }^{48}$ Yang dimaksud variant sekunder di sini adalah model pembacaan (qirā $\bar{a} t$ ) yang dipakai oleh literatur-literatur tafsir dalam memaknai suatu ungkapan dengan mengabaikan variant-variant alternatif lain yang sebenarnya lebih awal berkembang dan didukung dalam rujukan bahasa standar. 
Thabarīy dan Ibn Katsīr, di mana legal-fiction (fiksi hukum) telah menggeser dari hukum awal sesungguhnya (proto Islamic law) menjadi 'ilm al-farā 'idh.

Powers mendefinisikan sendiri apa yang ia maksud dengan "kritik literer": "By means of a literary analysis of several Qur anic inheritance verses and prophetic hadīth, I sought to demonstrate that the operation of the "science of the shares" is predicated upon series of assumptions--about readings, syntax, the meaning of words, etc.--that represent a secondary stage of development"49 (Dengan analisis sastra terhadap ayat-ayat al-Qur an dan hadits Nabi tentang waris, saya berupa untuk menunjukkan bahwa penerapan 'ilm al-fara $i d h$ didasarkan atas serangkaian asumsi--tentang pembacaan ( $q$ ira $\bar{a} \bar{t}$ ), sintaksis, makna sejumlah kata, dsb.--yang merupakan tahap sekunder dalam perkembangan).

Kritik literer, dengan demikian, adalah sebuah kajian kritis, sebagaimana yang dilakukan oleh David S. Powers terhadap penafsiranpenafsiran tentang kalālah yang berkembang dalam literatur-literatur tafsir klasik, seperti ath-Thabarī, dicari dasar-dasar pijakannya (seperti keseluruhan variant qirā' $\bar{a} t$ yang ada, termasuk yang dilupakan oleh ath-Thabarīi), lalu melakukan tafsiran ulang. Kritik literer sebenarnya tidak hanya diberlakukan terhadap konsep-konsep yang berbasis tafsir ayat, melainkan hadits-hadits dan pemahaman-pemahaman yang berkembang dalam fiqh.

Perangkat-perangkat tafsir untuk 'membedah' penafsiran-penafsiran klasik adalah perangkat-perangkat yang biasa diterapkan, namun tidak dicermati atau sengaja dilupakan: linguistik (bahasa; figh al-lughah), leksikografi (makna kata dalam kamus), semantik (makna kata; dalälah), grammar (struktur kalimat; nabwu), sintaksis (pecahan kata/ derivasinya; tashrīf). ${ }^{50}$ Penafsiran-penafsiran yang berkembang oleh Powers dilacak akar-akarnya ke sumber-sumber otoritatif, seperti Lisān al-'Arab karya Ibn al-Manzhūr, sebuah karya dalam bidang linguistik dan semantik di mana asal-usul suatu kata dijelaskan perkembangan makna awalnya dalam sejarah bahasa Arab, termasuk dalam syair Arab pra-Islam, serta variasi-variasi makna yang berkembang. Perujukan seperti ini bisa menjelaskan pilihan makna yang diambil oleh seorang penafsir di antara beberapa kemungkinan makna-makna lain, kamus bahasa Semit atau bahasa-bahasa lain, seperti bahasa Aram, Syria, Akkad, dan Ibrani ${ }^{51}$ yang

\footnotetext{
${ }^{49}$ Powers, Studies in Qur'ān and Hadìth, vi.

${ }^{50}$ Powers, viii, 48-50.

${ }^{51}$ Lihat contohnya dalam Powers, 48-50.
} 
mungkin berpengaruh pada suatu kosa kata Arab, seperti The Foreign Vocabulary of the Qur'an karya A. Jeffery dan Wörterbuch der Klassichen Arabishen Sprache (ed) M. Ullmann.

Sedangkan, metode kritik atas hadits-hadits yang berkembang sebagai sumber, David S. Powers mengembangkan metode kritik hadits Juynboll dan Speight (diuraikan dalam bagian kontribusi kelimuan).

Kedua, kritik sejarah (bistorical criticism) ${ }^{52}$ yang secara intensif diterapkan khususnya pada bagian kedua kajiannya, ${ }^{53}$ yaitu penunjukkan bukti-bukti sejarah tentang faktor-faktor penyebab terjadinya transformasi dari hukum purwa-Islam (proto Islamic law) ke 'ilm al-farā $i d h$. Powers, misalnya, berupaya menunjukkan bahwa sebab-sebab primer dan sekunder dapat dicari dalam sejarah politik, sosial, ekonomi, dan religius transformasi abad ke-1 $\mathrm{H}$. Transformasi pertama kali dipicu oleh perselisihan mengenai kekhalifahan, karena-menurut Powers-Abu Bakr yang tidak menerima dokumen penunjukkan dari Nabi Muhammad berkepentingan menghilangkan rujukan dalam QS.4: 12b yang berisi kemungkinan penunjukkan seorang ahli waris. Transformasi itu juga dipercepat oleh karena dalam hukum waris dengan adanya pembagian testamentair mendukung klaim dua khalifah pertama untuk menolak klaim atas warisan Muhammad yang diajukan berbagai keluarga Nabi. Sistem waris dengan model 'ilm al-fara 'idh dengan aturan-aturan wajib itu juga kemudian dianggap dapat memperkuat kohesi sosial.

Kritik sejarah sebagian diterapkan pada bagian dua tentang "Pembentukan Hukum Waris". Pada bagian ini, data kesejarahan digali dari sumber beragam: (a) literatur-literatur sejarah, seperti Kitāb Tārīkh ar-Rusul wa al-Mulūk ath-Thabarī, Thabaqāt Ibn Sa'd, al-Sìrah al-Nabawiyyah Ibn Hisyām, alBidāyah wa an-Nihāyah Ibn Katsīr, dan beberapa literatur sekunder, seperti koleksi Sezgin; (b) literatur-literatur hadist yang memuat sejarah, seperti

52“Kritik sejarah" memiliki kemungkinan dua pengertian. Pertama, kritik sejarah adalah bagian dari kerja ilmu sejarah, yaitu suatu cara (ada yang menyebutnya sebagai seni) membedakan antara yang benar dan keliru sehubungan dengan fakta masa lalu. Objek kajiannya adalah sumber-sumber sejarah, baik dokumen tertulis (tentang otentisitas integritas, makna, dan otoritas), bukti tidak tertulis, dan tradisi. Saya memahami kritik sejarah yang diterapkan Powers dalam pengertian sebagai bagian dari temuan sejarah yang bisa dijadikan bahan untuk melakukan kritik atas suatu konsep, pemahaman, penafsiran, termasuk kritik hadits yang muncul dari suatu moment sejarah. Lihat http://www.webspawner.com/users/historycriticism.htm (12 Juni 2020).

${ }^{53}$ Lihat Powers, Studies in Qur'ān and Hadīth, 141-255. 
kontroversi adanya wasiat politik Nabi menjelang wafat dalam Musnad Ahmad $b$. Hanbal (c) literatur-literatur tafsir; (d) literatur-literatur fiqh.

Kajian ini menerapkan pendekatan hermenutis (bermeneutical approach) yang diterapkan pada dua aspek. Pertama, hermenutika untuk kajian teks, karena untuk mengkritisi penafsiran-penafsiran lama yang sudah terbakukan, Powers memerlukan cara untuk menemukan makna ayat (reinterpretasi) yang diyakininya sebagai makna awal yang sesungguhnya. Powers sama sekali tidak secara eksplisit mengklaim pendekatannya terhadap ayat-ayat al-Qur'an sebagai pendekatan hermeneutis, tapi pendekatannya berbeda dengan penafsiran konvensional.

Contoh: QS. An-Nisāa: 12 tentang kalālah ${ }^{54}$

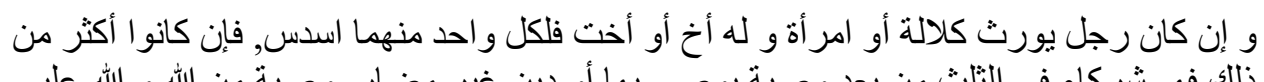
ذللك فهم شركاء فى الثلث من بعد وصية يوصنى بها أو دين غير مضار و وصية من الله و الله عليم الله

Titik kontroversi adalah pengharakatan (vokalisasi): أو امرأة, , ايورث , dan يوصى. Menurut penafsiran klasik, sebagaimana dianut oleh semisal ath-

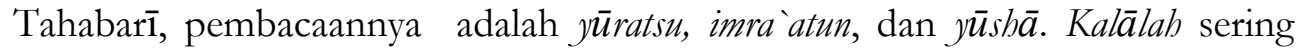
diartikan sebagai "mereka semua (ahli waris) selain ibu-bapak dan anak", atau sering dijelaskan sebagai "orang yang meninggal yang tidak memiliki anak atau orang tua/ ibu-bapak”.

Interpretasi baru Powers bertolak dari pengharakatan yūritsu, imra atan, dan $y \bar{u} s h \bar{\imath}$ dan mengartikan kalälah sebagai female in-law (menantu perempuan) sehingga ayat di atas diterjemahkan sebagai berikut:

Jika seorang pria menunjuk seorang menantu (perempuan) atau istri sebagai pewaris, dan pria itu memiliki seorang saudara atau saudari, maka setiap orang dari keduanya memperoleh seperenam. Jika mereka lebih banyak daripada itu, maka mereka bersekutu di dalam yang sepertiga, sesudah (penunaian) wasiat yang pria itu wasiatkan atau utang, dengan tidak menimbulkan mudarat. (Semua ini) sebagai perintah dari Allah. Allah Maha Mengetahui (lagi) Maha Penyantun. ${ }^{55}$

Bagaimana Powers sampai ke kesimpulan seperti itu? Pertama, Powers meninjau ulang atau mengkritisi sejumlah penafsiran-penafsiran yang beredar di kalangan mufassir. Tokoh paling representatif dari kecenderungan tafsir yang

${ }^{54}$ Lihat Powers, 25-61.

55Powers, 52-53. 
sangat ketat mengikatkan diri kepada tafsīr bi ar-riwāyah adalah ath-Thabarī dalam Jāmi' al-Bayān. Dalam kitab itu, Thabarī sebenarnya menyebutkan keberadaan tidak kurang dari 27 syawābid (bukti-bukti pendukung) terpisah lain. Ada 14 syawāhid menjelaskan arti kalālah sebagai "orang yang mati (almarhum) yang tidak meninggalkan ibu-bapak atau anak" dan 20 syawāhid menjelaskannya sebagai "semua ahli waris kecuali ibu-bapak dan anak", jadi ahli waris. Ada satu riwayat yang menggabungkan keduanya. Ath-Tahabarī mengikuti pendapat tentang arti kalālah sebagai ahli waris kecuali ibu-bapak dan anak dengan proses eliminasi dengan mencermati perdefinisi. Yang menjadi pertanyaan Powers adalah mengapa ath-Thabarī mengabaikan atau tidak mencermati keberadaan 13 syawähid (oleh para mufassir sesudahnya justeru dihilangkan) tentang arti kalälah yang bertentangan dengan pembacaan tradisional? Kegelisahan ath-Thabarī adalah wajar karena pembacaan tradisional tidak bisa menyelesaikan kesulitan gramatikal, misalnya: ada dua subjek (rajulun aw imra 'atun) dalam qira at: wa in kēana rajulun yüratsu kalälatan aw imratun walahu akhun aw ukbtun..., sedangkan kata lahu merujuk ke salah satu di antara keduanya (rajulun). Untuk menjawab pertanyaan "mengapa" itu, Powers keluar dari analisis teks itu ke situasi sejarah ketika ath-Thabarī hidup. Dari teks ke konteks. Menurut Powers, adanya 13 syawāhid ("anekdot-anekdot" dalam istilah Powers yang sebenarnya adalah riwayat-riwayat) yang diabaikan itu sebenarnya memuat ketidakpuasan 'Umar bin al-Khaththāb terhadap penjelasan yang ada, sampai-sampai Rasulullah menyodok dadanya karena penjelasan QS. An-Nisā : 176 dianggap beliau sudah cukup. Di antara andekdot itu termuat riwayat bahwa 'Umar berniat akan membuat penjelasan yang bisa diterima oleh semua pembaca al-Qur'an. Itu artinya bahwa selama abad pertama pasca-wafat Nabi diskusi tentang QS. An-Nisā': 12 dan 176 sangat terbuka daripada tahun-tahun segera sesudahnya. Buktinya, berdasarkan Ibn Katsīr, anekdot-anekdot itu tidak disebutkan lagi dan hanya disebutkan pendapat yang dianggap benar. Menurut Powers, pengedaran definisi yang "benar" itu dilakukan oleh sejumlah sahabat, termasuk 'Alī, dan tābi' at-tābi 'īn yang dari mereka muncul isnād. Itu berlangsung tanpa "perlawanan”. Proses itu juga semakin lancar ketika 'ijma $\bar{a}$ ' semakin terkonsolidasi. Peran kontrol terhadap cara membaca al-Qur'an (qirā 'ât $)$ berupa pengharakatan/ vokalisasi QS. an-Nisā' 12 dan 176 juga dimungkinkan dengan ijm $\bar{a}$ ' itu. Jadi, mengapa ath-Thabarī tidak begitu tertarik mencermati 13 syawāhid itu adalah karena 
proses historis ortodoksi yang panjang, termasuk kekuatan 'ijmā' dan varian qirā 'āt yang berbasis dari kontrol gramatika Arab. Analisis ini paralel dengan kritik Arkoun atas ortodoksi dalam Lectures du Qoran. ${ }^{56}$

Jadi, Powers semula bertolak dari analisis semantik dan sintaksis, kemudian beralih ke analisis konteks. Dari model penggunaan data sejarah, kritik Powers itu mengambil bentuk kritik sejarah. Namun, dari dari keseluruhan argumen dalam contoh ini dalam konteks pembacaan baru QS. 4: 12. Ada beberapa langkah Powers untuk menetapkan makna baru itu setelah kritik pembacaan tradisional. Pertama, ia bertolak dari 13 syawāhid itu. Kedua, memecahkan kesulitan gramatikal dengan vokalisasi $y \bar{u} r i s t u$, imra atan, dan $y \bar{u} s h \bar{\imath}$ (sintaksis dan semantik). Ketiga, analisis semantik akar kata (fiqh al-lughah) kata kalālah dalam rumpun bahasa Semit (Akkad, Aram, Syria, dan Ibrani). Identifikasi makna kamus diuji kemudian dengan meneliti konteks di mana kata kalālah muncul dalam berbagai teks awal awal. Di sini ia merujuk ke puisi Arab pra-Islam. Meski demikian, ia tidak selalu yakin dengan penjelasan leksiografer, seperti penjelasan Ibn Manzhūr terhadap suatu bait puisi yang mengilustrasikan tentang kemarahan bapak kepada anak jika ia diperlakukan tidak adil, kecuali para klein kalālah (saudara, paman, keponakan, dan kerabat lain) yang justeru dianggap tidak rasional oleh Powers dengan penjelasan 'ashabiyyah (solidaritas kelompok) Ibn Khaldun bahwa berdasarkan prinsip itu orang akan berharap

\footnotetext{
${ }^{56}$ Menurut Arkoun ilmu-ilmu al-Qur'an dapat diklasifikasi kepada tiga. Satu di antaranya adalah pengetahuan-pengetahuan teknis dan nalar keagamaan. Pengetahuanpengetahuan teknis yang berhasil dihimpunkan oleh tradisi skolastis-dalam istilah Arkounoleh as-Suyûthî, pertama-tama adalah analisis linguistik: kosa kata, morfologi, sintaksis, semantik, retorika, dan persajakan. Di sini, Arkoun melihat bahwa persoalan seperti penyebaran dan pembentukan mushbaf yang semula berupa catatan-catatan berserakan bergeser menjadi "solusi-solusi" yang sejak abad ke-6 H menjadi definisi kredo Islam. Nah, ada proses timbulnya wacana al-Qur'an, kemudian fungsi suatu nalar keagamaan yang menguasai berbagai pemaknaan wacana dengan bantuan pengetahuan teknis (gramatika bahasa). Menurutnya, perlu juga diketahui sejauh mana nalar teknis "diabdikan" untuk membentuk suatu nalar keagamaan. Bukankah ada perbedaan antara wacana al-Qur'an dengan nalar yang sudah dipahami atas dasar

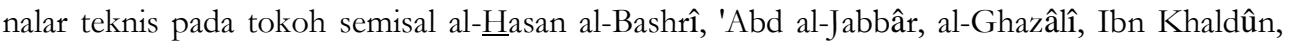
atau as-Suyûthî? Oleh karena itu, perbedaan analisis bahasa dengan sejumlah perbedaan aliran bahasa Arab menjadi alat pembakuan nalar itu. Lihat, lebih lanjut, Mohammed Arkoun, Lectures du Qoran, terjemah Machasin dengan judul Berbagai Pembacaan Quran (Jakarta: INIS, 1997), 10-28. Dugaan yang sama dikemukakan oleh A. Jeffery dalam Materials for the History of the Text of the Qur'an (dalam Powers, h. 60, footnote 46) bahwa ketika ia mengumpulkan semua ragam qirā’at dari naskah-naskah kuno dari karya para mufassir dan filosof ditemukan adanya tujuan-tujuan tafsir untuk melanggengkan ortodoksi.
} 
dukungan dari saudara sebanyak dukungan dari bapak. Keempat, apa yang disebutnya sebagai "semangat situasi hipotetik" (kasus pengandaian) yang digambarkan dalam QS. an-Nisā': 12b. Ini adalah pembagian warisan yang diandaikan jika menerima pembacaan baru itu.

Proses Powers tersebut adalah sebuah proses hermenutis dari kritik hingga menetapkan makna baru. Semula ia bekerja keras "dalam teks" dengan media bahasa ke "konteks" secara kreatif dengan menghubungkan pemaknaan yang ada dengan situasi sejarah dan konsep-konsep yang muncul.

Kedua, hermeneutika untuk kajian sejarah. Penggunaan hermenutika dalam kajian sejarah adalah hal wajar, ${ }^{57}$ karena sebagain data sejarah adalah berupa dokumen atau teks yang perlu diinterpretasikan. Ayat dan hadits yang memuat suatu peristiwa bisa diperlakukan sebagai dokumen sejarah. Di samping itu, ayat-ayat atau hadits-hadits juga muncul dari konteks sejarah yang sempit (asbāb an-nuqu $\bar{u})$ atau lebih luas (konteks sosio-historis Arab), jadi juga bersifat kesejarahan. Interpretasi Powers terhadap QS. 4: 12a tentang kewarisan suami istri yang dikatakannya hanya berlaku dalam situasi normal bisa dipahami, menurutnya, dalam konteks Timur Dekat. Begitu juga, 13 syawāhid (riwayat-riwayat) yang disebutnya sebagai argumen-argumen historis yang didiskusikan di atas harus diinterpretasikan.

\section{Alur Argumentasi}

Pada bagian I, Powers mengemukakan apa yang ia sebut sebagai proto Islamic law, yaitu hukum Islam yang awal yang semula diterima dari Nabi dan secara otentik berasal dari ajaran al-Qur`an.

Dalam hal ini, ia menyoroti beberapa hal. Pertama, kewarisan lewat wasiat (bab 1). Di sini, Powers melakukan penafsiran ulang terhadap QS 4: 12b tentang kalälah. Dari sini, ia ingin menunjukkan bahwa hukum Islam awal tentang waris sebenarnya memberi keleluasaan kepada setiap orang untuk menyerahkan hartanya dengan wasiat, bukan dengan hitungan matematis yang rumit dan kaku.

Kedua, kewarisan suami isteri (bab 2). Menurutnya, dalam keadaan normal, suami dan isteri tidak saling mewarisi, tidak seperti asumsi yang berkembang pada umumnya. Untuk memperkuat kesimpulannya ini, Powers mengangkat kasus yang di mana ada 2 persoalaan kontroversial dengan

${ }^{57}$ Lihat, misalnya, uraian Ian Wright, "History, Hermeneutics, Deconstruction”, dalam Jeremy Hawthorn (ed.), Criticism and Critical Theory (Baltimore: Edward Arnold, 1984), 83-98. 
penyelesaian yang dianggapnya aneh. Kasus pertama: 'Umariyatān. Menurutnya, formula 1: 2 sebagai 'prinsip' dalam kewarisan perempuan dan laki-laki ternyata bertentangan dengan 'Umariyatān, di mana bagian perempuan lebih besar daripada bagian laki-laki. Misalnya, suami meninggalkan isteri dan ibu bapak. Menurut pandangan ulama/ penafsir yang non-literalis, seperti Zamakhsyarī, menyatakan bahwa ibu mendapat $1 / 3$ dari sisa, sedangkan menurut pandangan yang dianggap literalis, yaitu penafsiran dari Ibn 'Abbās dan menurut pandangan Ibn Hazm, ibu mendapat 1/3 dari keseluruhan. Dengan cara membandingkan antara kasus ini dengan formula al-Quran sendiri, Powers berkesimpulan bahwa di tangan para ulama/ penafsir "alQur'an tampak bertentangan dalam dirinya sendiri”. Dengan demikian, penafsiran klasik tidak memuaskan dan kontroversi diselesaikan cukup dengan ijmā'.

Kasus kedua; 'aul (pembagian lebih dari $100 \%$ ). Menurut pandangan yang non-literalis ('Umar), porsinya harus dikurangi, sedangkan menurut kalangan literalis, yaitu Ibn 'Abbās \& Ibn Hazm, pengurangan bagian anak perempuan dan saudari justeru bertentangan dgn al-Qur`an. Dalam kasus seperti ini, Powers kemudian menilai bahwa "fiqh berseberangan (berrtentangan) dengan al-Qur'an".

Dari pertentangan yang muncul antara keduanya tersebut, Powers kemudian mengajukan hipotesis bahwa kontradiksi yg tampak dalam al-Qur'an terjadi mungkin karena perubahan penafsiran yang tak disadari, atau al-Qur'an memang sengaja membuat warisan tergantung atas kekerabatan (tidak didasarkan dengan hitungan matematis yang ketat).

Untuk membuktikan hipotesisnya, Powers mengemukakan fakta. Pertama, dari al-Qur`an sendiri, yaitu teks QS. 4: 8. Kedua, dari aspek analisis kesejarahan, hukum Romawi yang diterapkan di Timur Dekat mungkin berpengaruh terhadap pembentukan hukum Islam bahwa kewarisan suami isteri dibentuk atas dasar pertimbangan agar istri/suami yang tidak mendapat mahar (padahal perkawinan sudah berjalan) tetap mendapat jaminan hidup ketika pasangannya meninggal dan tidak ada wasiat. Powers juga menegemukan adanya kasus hipotetis yang tidak bisa diselesaikan, kecuali jika diasumsikan bahwa suami/isteri tidak menerima warisan: (1) suami/ istri; (2) ibu yang mendapat $1 / 3$ warisan; (3) ayah yang mendapat dua kali lipat bagian ibu. Ketiga, sunnah. Sejauh penelusuran Powers, Nabi Muhammad tidak memberi warisan kepada isteri-isterinya. Keempat, institusi mahar dimaksudkan untuk 
menjamin kehidupan janda yang ditinggal suami, karena dalam kasus janda 'tak bermahar', ada tiga arus pendapat Sahabat Nabi yang tidak memiliki dasar kuat, kecuali pendapat ibn Mas' 'ūd yang kemudian diikuti oleh al-Syāfi'ī bahwa janda tersebut menerima mahar mitsl dan warisan sekaligus. Kelima, pertimbangan lain, yaitu (a) dalam diyat suami, istri tidak berhak mewarisi (berdasarkan pendapat 'Umar); (b) dalam kasus radd, hanya keluarga terdekat almarhum suami yang berhak mendapatkan warisan; (c) menurut fiqh Syī'ah, istri tanpa anak tidak mewarisi; (d) Survey etnografi bahwa kaum muslimin di seluruh dunia mengabaikan kewarisan perempuan.

Dari berbagai fakta kesenjangan yang ia kemukakan, analisis, dan kritik, ia kemudian berkesimpulan. Pertama, penafsiran klasik para ulama terhadap QS 4: 12a dalam hal kewarisan suami isteri telah menjungkirbalikkan penafsiran; dari semula yang seharusnya hanya "pengecualian" menjadi norma. Penafsiran keliru ini mengakibatkan al-Qur'an kemudian tampak kontradiktif dalam ajarannya di satu sisi, dan di sisi lain, fiqh yang berkembang pada masa awal, sebagaimana dikemukakan tokoh-tokoh awal dengan pendapatnya, menyimpang dari teks eksplisit ayat. Kedua, dengan melihat konteks kesejarahan yang mendahului konteks turunnya al-Qur`an, khususnya kepterpengaruhan dengan hukum Romawi, menurutnya, kewarisan sebenarnya didasarkan lebih atas dasar kekerabatan, seperti terlihat dari adanya keselarasan dengan ide ini.

Kajian-kajian terdahulu telah banyak dilakukan berkaitan dengan hukum waris dalam Islam, salah satunya adalah tentang kewarisan ab intestato. Pada bab 3, ia mengritik "teori pelapisan" yang mengatakan bahwa bahwa hukum waris waris Islam 'melapisi' hukum tribal Arab yang ada sebelumnya dengan beberapa perubahan. Teori ini dianggap keliru karena beberapa alasan. Pertama, konsep 'ashabah dalam Islam berbeda dengan prinsip senioritas dalam adat suku-suku Arab. Kedua, dalam Islam, dikenal adanya klasifikasi ahli waris berdasarkan ahli 'primer' dan 'sekunder'. Kedua, formula 1: 2 (perempuan: laki-laki) hanya berlaku bagi ahli waris 'primer', sedangkan pada ahli waris sekunder, perbedaan porsi laki-laki dan perempuan harus diabaikan. Ketiga, ahli waris almarhum adalah yang sedarah dengan hirarki tanpa melihat kelamin: (1) anak-anak, (2) ibu-bapak, dan atau saudara/saudari, dan (3) saudara/saudari saja.

Kesimpulan penting yang ditarik oleh Powers adalah bahwa ilm alfarāidh bukanlah hukum Islam awal yang sesungguhnya (proto Islamic law), 
melainkan hukum Islam yang telah dimanipulasi oleh para penafsir melalui penafsiran ayat sedemikian rupa, sehingga pembagian warisan bisa terjadi dengan hasil pembagian melebihi 100 persen, dan ini adalah tidak logis.

Bagaimana perubahan proto Islamic law itu menjadi 'ilm al-farā $i d h$ ? Pada bab 4, Powers menuturkan bahwa selain melalui media penafsiran seperti itu, peralihan ini juga dikondisikan berbagai konteks yang satu sama sekali saling menopang. Pertama, faktor utama, yaitu historis-politis tentang suksesi politik setelah Nabi saw wafat. QS. 4: 12b tentang penunjukkan ahli dimanipulasi oleh Abū Bakr dan penggantinya. Kedua, faktor pendukung, yaitu konteks sosial, ekonomi, dan situasi keagamaan, karena sistem waris dengan aturan wajib dipahami lebih cenderung sebagai perwujudan dari hukum Tuhan dibandingkan sebagai penunjukkan atas dasar kebebasan yang sebenarnya akan meningkatkan kohesi sosial, karena dengan begitu ketentuan yang diikuti secara kekeluargaan dirasakan lebih egaliter melalui bagian-bagian itu. Ketiga, faktor pemahaman keagamaan, terutama pemahaman terhadap ayat-ayat al-Qur'an yang terkait, dalam hal ini literalisme tafsir berkembang dan mendukung perubahan itu, misalnya cara pembacaan (qirā $\bar{a} t)$ terhadap ayat tertentu, pemenggalan ayat, dan penafsiran terhadap QS. 4: 11a, 11b, 12a, 12b, dan 176 membentuk penafsiran terhadap ayat-ayat kewarisan ( $\bar{a} y \bar{a} t$ al-mìrāts).

Tidak hanya penafsiran, ilmu-ilmu tentang al-Qur'an ('ulüm al-Qurān) juga ikut mengkondisikan pembacaan, penafsiran al-Qur`an, dan perubahan ke ilmu waris ini. Pertama, teori tentang pembatalan atau penganuliran ayat alQuran (naskh). Para ulama dan penafsir generasi awal sudah meyakini terjadinya penganuliran ayat wasiat. Melalui penelusuran sejarah, Powers (pada bab 5) melacak bahwa ayat wasiat sebenarnya berlaku hingga $632 \mathrm{M}$, namun kemudian dikatakan dianulir dengan teori naskh yang dengan tiga justifikasi, yaitu al-Qur’an, hadīts, dan konsensus ulama (ijm $\bar{a}$ ') yang muncul melalui proses sejarah antara abad ke-7-8 M. Bahkan, ironisnya kaedah fiqih yang dianut ulama untuk membakukan ketentuan pembatalan itu, yaitu 'tidak ada wasiat bagi seorang waris' (lā washiyyah li wā rist) diubah menjadi hadīts. Kedua, ilmu tentang konteks atau latar belakang pewahyuan (asbāb al-nuг̄ūi) yang berbarengan dengan perubahan ke 'ilm al-farā $i d h$ hanya menjelaskan pembacaan ( iri $\bar{a} \cdot \bar{a} t)$ sekunder tentang ayat-ayat yang menjelaskan legislasi alQur'an. Itu artinya, bahwa telah terjadi justifikasi lewat ilmu-ilmu al-Qur`an terhadap perubahan itu (bab 6).

Dengan pembuktian ini, Powers berkesimpulan bahwa hukum Islam, dalam hal ini hukum waris, sudah terbentuk dengan legislasi al-Qur`an, tidak 
seperti tesis tesis Schacht yang menyatakan tidak ada peran al-Qur`an dalam proses legislasi itu. Akan tetapi, tidak seperti klaim para ulama klasik bahwa perubahan ilmu itu memang secara otentik didasarkan oleh penafsiran yang benar terhadap ayat al-Qur an, Powers membuktikan di sisi lain bahwa secara historis, perubahan itu juga dibentuk oleh berbagai manipulasi penafsiran dalam kondisi-kondisi tertentu yang tidak bisa seluruhnya dikatakan sebagai representasi otentik wahyu.

Powers menawarkan beberapa konsep penting sebagai bagian dari hasil kajiannya. Pertama, proto-Islamic Law ("hukum purwa-Islam"), yaitu hukum yang sebenarnya diperkenalkan oleh Nabi Muhammad sendiri, dalam hal ini, sistem yang tidak hanya mengizinkan kewarisan testamentair, termasuk menentukan siapa saja yang berhak mewarisi, melainkan juga suatu sistem yang bebas dari kerumitan matematis 'ilm al-farā $i d h$. Model hukum Islam ini direkonstruksi melalui pemahaman terhadap makna awal dan sesungguhnya ayat-ayat dan hadits-hadits wasiat dan waris. ${ }^{58}$ Oleh karena itu, penafsiran tradisional harus ditafsir ulang (reinterpretasi). Kedua, kewarisan testamentair, yaitu kewarisan yang merupakan bagian dari proto-Islamic law yang didasarkan atas wasiat hukum dengan menunjuk orang-orang tertentu untuk mewarisi. Ahli waris testamentair adalah ahli waris yang berhak menerima harta warisan atas dasar penunjukkan/ wasiat tersebut. ${ }^{59}$ Ketiga, kewarisan ab intestato, yaitu kewarisan yang disyariatkan dalam hukum purwa-Islam ketika tidak ada wasiat yang didasarkan atas bagian-bagian (fardh) yang telah ditentukan, seperti setengah, seperempat, sepertiga, dua pertiga, dan seperenam, kepada orang-orang yang ditentukan pula (ahli waris ab intestato): anak sebagai ahli waris primer (QS. 4: 12a), ibubapak dan saudara/saudari sebagai ahli waris primer (QS.4: 11b), beberapa saudara/saudari sebagai ahli waris satu-satunya (QS. 4: 176). Ahli waris primer adalah ahli waris utama yang paling berhak dalam urutan prioritas kekerabatan sedarah alamarhum, tapi terkait dengan jenis kelamin: (a) anak-anak; (b) ibubapak dan/ atau saudara/saudari; (c) saudara/ saudari saja. Sedangkan, paman, sepupu, dan semisalnya, berada di bawah saudara/ saudari. Ahli waris yang menempati kelas di bawah setelah ahli waris utama/ primer disebut ahli waris sekunder. Kedudukan ahli waris dalam urutan prioritas itu tergantung pada situasi, kecuali anak-anak yang tetap menjadi ahli waris primer sejak dalam sistem waris purwa-Islam. ${ }^{60}$

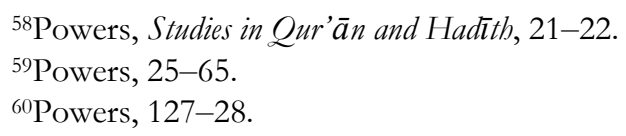




\section{Uraian Perbab}

Kajian David S. Powers diawali (Pendahuluan) dengan kegelisahan akademisnya atas anomali-anomali yang terjadi dalam kajian hukum Islam. Kritik terutama ditujukan kepada tesis Joseph Schacht yang kemudian memunculkan sejumlah kajian dalam bidang hadits, karena Schacht membangun tesis tentang back-projectionnya atas otentisitas hadits melalui kitabkitab hadits yang ditulis dua abad pasca-Nabi. Powers mengemukakan dua arus studi hadits: studi-studi yang bertolak dari kritik atau revisi terhadap Schacht, seperti Sezgin, Abbott, dan Juynboll, dan al-A'zhamī. Di sisi lain, ada tradisi Islam yang melihat hukum Islam sebagai manifestasi wahyu. Kegelisahan terhadap keadaan seperti itu kemudian digambarkan oleh Powers dengan bagaimana tradisi Islam memandang 'ilm al-fara 'idh, bagaimana Barat dengan teori pelapisan memandang asal-usul hukum waris Islam, dan terakhir, rekonstruksi Powers tentang apa yang disebutnya "hukum Islam yang diterima Muhammad" (proto Islamic law). Tesisnya adalah bahwa al-Qur' an mesti menjadi sumber legislasi hukum waris, namun telah terjadi proses transformasi dari hukum awal ke ilm al-fara $\bar{\imath}$ idh.

Bukti dan argumen disusun atas dua bagian. Bagian pertama berisi rekontruksi Powers tentang apa yang disebutnya "hukum Islam yang diterima Muhammad" (proto Islamic law) yang terdiri dari 3 bab: bab 1 tentang kewarisan testamentair, yaitu kewarisan atas dasar wasiat hukum di mana ia mengemukakan pembacaan baru QS 4:12b, bab 2 berisi penjelasan tiga kasus kontroversial waris ('umariyyatān, 'aul, ungkapan ayat "...sesudah wasiat yang ia buat atau utang") yang berujung pada kesimpulan bahwa dalam keadaan normal suami-istri tidak saling mewarisi, dan bab 3 tentang kewarisan ab intestato yang berisi bahasan tentang kedudukan 'ashabah pada hukum waris awal dan kedudukan para ahli waris yang ditentukan bagiannya yang menurut Powers harus dibedakan antara ahli waris primer dan ahli waris sekunder.

Bagian kedua berisi analisis kesejarahan tentang faktor historis-politis yang menyebabkan "hukum Islam yang diterima Muhammad", sebagaimana diuraikan pada bagian pertama itu mengalami transformasi atau diubah menjadi 'ilm al-farā 'idh; dari semula berupa sistem kewarisan atas dasar wasiat dan suka rela dengan garis kekerabatan darah terdekat menjadi sistem pembagian fardh dengan hitungan matematis yang rumit. Bagian kedua berisi 3 bab: bab 4 tentang faktor politis sekitar isu kekhalifahan dan wasiat politik Nabi serta klaim atas warisan Nabi, bab 5 tentang isu kontroversial dalam 'ulüm al-Qur'ān, 
yaitu naskh, yang digunakan untuk menjelaskan adanya penghapusan ayat wasiat yang kemudian menjadi dasar kitab 'ulüm al-Qur'ān dan ushūl al-fiqh yang berperan dalam pembentuk 'ilm al-farā 'idh itu, dan begitu juga cabang bahasan

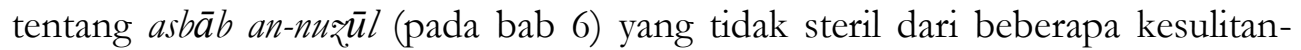
kesulitan yang sukar dijelaskan dalam proses berdirinya disiplin ini, seperti problem "rangkap sebab" (asbāb muta'addidab). Asbāa an-nu₹̄̄l diedarkan pada saat hukum awal waris diganti dengan 'ilm al-farā $i d h$, sehingga pemahaman sekunder tentang legislasi al-Qur'an hanya diberikan penjelasan oleh asbāb an$n u \bar{u} \bar{l}$ yang cocok dengannya.

Bagian akhir kajian Powers dilengkapi dengan ringkasan dan kesimpulan uraian-uraian pada bab-bab sebelumnya. Beberapa kutipan ayatayat yang didiskusikan dapat diakses di affendiks

\section{Menilai Kontribusi Powers}

Pertama, dalam konteks kajian hukum Islam, khususnya jurisprudensi Islam (ushül al-fiqh), kajian David S. Powers telah berhasil menunjukkan alQur'an sebagai legislasi pertama Islam, suatu sumber normatif pertama, fakta yang dilupakan beberapa kajian hukum islamisis. Namun, pada saat yang sama, Powers menunjukkan historisitas penafsiran ayat-ayat al-Qur'an yang dibentuk oleh suatu model pembacaan ayat oleh generasi-generasi awal hingga memunculkan tafsir ayat-ayat mīräts. Historisitas tersebut mampu menjelaskan berbagai bentuk penyimpangan atau manipulasi pemaknaan ayat, fakta yang sering dilupakan oleh kajian hukum Muslim. Jadi, kajian ini bersifat kritis terhadap dua cara pandang yang berbeda: antara idealist dalam pendekatan normatif kaum muslimin dan reductionist pendekatan kesejarahan kalangan islamisis. Hasilnya adalah bahwa harus dibedakan mana hukum waris Islam awal yang sesungguhnya diterima Nabi Muhammad dengan ' $i l m$ al-farā $i d h$ yang muncul karena keadaan tafsir dan hadits serta pemahaman sedemikian rupa, dan kondisi-kondisi historis-politis. Proto Islamic law (hukum Islam awal) berbeda radikal dengan 'ilm al-farā $i d h$.

Kedua, temuan metodologis. Dipengaruhi oleh "keraguan yang sehat" (bealtby scepticism) Juynboll tentang belum mencukupinya ujian kebenaran haditshadits Nabi dari dari segi kesejarahan (bistorisity) dan "suatu bentuk pencarian latar alami" (a form in search of a natural setting) Speight, ${ }^{61}$ Powers mengembangkan cara mengkritik otentisitas hadits dengan kritik sejarah, suatu

${ }^{61}$ Powers, 205-6. 
hal yang mirip dengan kritik sejarah Fazlur Rahman (ia menyebut metodenya sebagai "full historical treatment" dalam Islamic Methodology in History). ${ }^{62}$ Namun, Rahman menerapkannya dengan ketentuan bahwa jika suatu hadits muncul kemudian dalam suatu periode sejarah belakangan yang disusul dengan hadits yang berlawan (hadits - anti-hadits), otentisitasnya diragukan. Berbeda dengan Rahman yang berada "di luar" (jika diberlakukan kaedah itu, ia tidak peduli lagi dengan keadaan sanad-sanad hadits yang banyak), Powers meneliti suatu ungkapan muncul dalam koleksi apa dan siapa (fuqaha, misalnya) dan kapan, dan melacak perkembangan sanad-sanad pada abad-abad sesudahnya dalam koleksi hadits-hadits dengan cara membandingnya. Metode kritik yang dikembangkannya dari Juynboll seperti itu diterapkannya pada ungkapan " $/ \bar{a}$ washiyyat li wārits" yang muncul pertama dalam Risālah asy-Syāfi' '̄ (w. 820) yang digunakan untuk mendukung doktrin naskh ayat wasiat. ${ }^{63}$ Ungkapan itu muncul sebagai pepatah hukum antara seperempat abad pertama/ kedelapan hingga seperempat terakhir abad itu juga ketika mulai dipakai oleh Mālik dalam Muwaththa: Pada paruh pertama abad ke-9 versi riwayat diedarkan pertama kali dalam Mushannaf 'Abd ar-Razzāq (w. 826) hingga berkembang sebagai hadits dalam kitab-kitab hadits, demikian Powers.

\section{Neo-tradisionalis: Antara Revisionis dan Tradisionalis Aspek Revisionis}

Orientalis revisionis adalah kalangan Barat yang meragukan klaim umat Islam atas kebenaran tradisi yang mereka anut, karena menurut mereka, harus ada bukti yang otentik dan tidak bias. ${ }^{64}$ Ketika mengulas metode John Wansbrough dalam Qur`anic Studies, Andrew Rippin mencoba memformulasi metode kalangan revisionis, yaitu dengan mempertanyakan "apa buktinya?" Dalam konteks al-Qur`an, misalnya, "apa bukti yang mendukung keakuratan sumber-sumber tradisional pengumpulan al-Qur'an segera setelah wafatnya Muhammad". "Titik-tolak Wansbrough lebih radikal: semua korpus dokumentasi Islam awal harus dilihat sebagai 'sejarah penyelamatan". ${ }^{65}$

${ }^{62}$ Rahman, Islamic Methodology in History, vi.

63Powers, Studies in Qur'ān and Hadith, 196.

${ }^{64}$ Rahman, “Tren Kajian Al-Qur'an Di Dunia Barat," 3-4.

${ }^{65}$ Andrew Rippin, Literary Analysis of Qur'ān, Tafsìr, and Sìra: The Methodologies of John Wansbrough", dalam Approaches to Islam in Religious Studies, ed. Richard C. Martin (Tucson: The University of Arizona Press, 1985), 153-54. 
"Influenced by revisionist scholarship on the subject of Muhammad and the Qur'an that had appeared recently, I began to entertain the possibility that what we know as the Islamic law of inheritance (in Arabic, 'ilm al-farā' 'id, or science of the shares) is not identical to the system of inheritance revealed to Mubammado6 (Dipengaruhi oleh kesarjanaan revisionis tentang persoalan Muhammad dan al-Qur an yang akhir-akhir ini muncul, saya mulai menyuguhkan kemungkinan bahwa apa yang kita kenal sebagai hukum Islam tentang waris (dalam bahasa Arab, 'ilm al-farā'id, atau ilmu tentang bagian-bagian) tidak identik dengan sistem waris yang diwahyukan kepada Muhammad)." Ini adalah sebuah "pengakuan" oleh seorang David S. Powers sendiri.

Revisionisme Powers di sini diidentifikasi setidaknya dalam dua hal. Pertama, dalam hal revisinya terhadap Joseph Schacht. Menurut Powers, hukum Islam tidak bisa tumbuh dan berkembang tanpa peran al-Qur`an di dalamnya, tidak seperti tesis Schacht yang melacak munculnya hukum Islam pasca-kenabian. Powers mengatakan, "onyone who wants to shed light on the origins of Islamic positive law ought to begin with the Qur'anic legislation in the field of family law, inheritance, and ritual' (siapa pun yang ingin melacak asal-usul hukum positif Islam, ia harus memulainya dari legislasi al-Qur'an di bidang hukum keluarga, waris, dan ritual). ${ }^{67}$ Oleh karena itu, Powers dalam hal ini tidak seperti kalangan atau orientalist in oled fashion (orientalis gaya lama), seperti Noeldeke, Muir, dan Edward Sell yang memfokuskan kajiannya pada persoalan otentisitas dan asalusul al-Qur`an. Dalam konteks ini, ia sejajar dengan orientalis-orientalis kontemporer semisal Andrew Rippin, Gerald Hawting, Patricia Crone, Michael Cook, Christoph Luxenburg, dan Gerd Puin.68

Kedua, ketidakpercayaan Powers terhadap sumber-sumber dalam tradisi Islam sendiri. Sebagaimana dikemukakan, ia mengritik habis penafsiranpenafsiran generasi awal, seperti Ibn 'Abbās, yang menjustifikasi persoalan waris. Bahkan, ia mengritik pedas ilmu-ilmu pendukung penafsiran, seperti ilmu tentang penganuliran atau pembatalan (naskh) ayat al-Qur`an, ilmu qirā $\bar{a} t$, dan asbāb al-nu₹z̄l. Menurutnya, ilmu-ilmu ternyata digunakan untuk memanipulasi penafsiran yang seharusnya menjadi penafsiran yang mereka anut, di bawah kondisi politik tertentu pada masa awal Islam.

\footnotetext{
${ }^{66}$ Powers, Studies in Qur'ān and Hadìth, vi.

${ }^{67}$ Powers, 7.

${ }^{68}$ Rahman, “Tren Kajian Al-Qur'an Di Dunia Barat,” 3.
} 
Pergeseran kajian-kajian orientalisme ini tentu merupakan akibat logis dari berbagai faktor yang mendorongnya. Kritik sistematis Edward Said dalam Orientalism tentu saja berimpak besar dalam pergeseran ini. Dalam penggambaran model kritis Michael Foucault, Edward Said menggambakan orientalisme bukan sekedar sebuah wacana yang diciptakan oleh Barat untuk mendominasi, melainkan mendefinisikan diri mereka. Timur kemudian digambarkan sebagai wujud tidak bertahan lama dan terbelakang, sedangkan Barat adalah kuat. ${ }^{69}$

\section{Aspek "Tradisionalis"}

Orientalisme tradisionalis berkutat pada persoalan asal-usul (otentisitas) al-Qur`an, antara lain dengan membuktikan adanya pengaruh tradisi YahudiKristen terhadap pembentukan doktrin al-Qur'an. Kini, Powers tidak mempersoalkan ini lagi yang tampak ketinggalan dalam wacana orientalisme, melainkan menggeser analisis keterpengaruhan itu pada kaum muslim generasi awal dengan tradisi hukum yang hidup di Hijaz. Ia tampak berhati-hati dalam persoalan "keterpengaruhan" hukum Islam dengan hukum adat Arabia praIslam, karena persoalan bias jähiliyyah. Menurutnya, dalam hukum tribal (adat suku) di Hijaz, kewarisan diatur dengan prinsip senioritas, bukan atas prinsip keturunan-langsung. ${ }^{70}$ Menurut Powers, memahami tradisi tribal Arab ini menjadi kunci penting dalam memahami hubungan tradisi ini dengan legislasi al-Qur`an. ${ }^{71}$

Analisis yang merupakan tipikal Barat dalam melihat hukum Islam, yaitu "keterpengaruhan" hukum waris Islam yang dipahami oleh para ulama masa awal dengan hukum Romawi yang pernah diberlakukan di propinsipropinsi Timur Dekat. Dengan membandingkan anatar QS. 4: 12a dengan Novella 53: 6, Powers ingin membangun kesimpulannya bahwa suami-istri menurut ayat ini itu dalam keadaan normal tidak saling mewarisi dengan bukti kesejarahan bahwa ketika al-Qur'an diturunkan beberapa masyarakat Timur Dekat sejak abad ke-4 SM menghadapi masalah istri yang "tidak mendapatkan mahar". "Keadaan normal" yang dimaksud di atas adalah jika istri telah mendapatkan mahar ketika suaminya telah meninggal. Itu artiya bahwa disyariatkannya kewarisan suami istri semata-mata hanya dalam keadaan jika

${ }^{69}$ Lihat tentang Said dan pendekatannya, dalam Hande Tekdemir, "Critical Approaches to Edward Said's Orientalism.," Social Sciences Review of the Faculty of Sciences \& Letters University of Uludag/Fen Edebiyat Fakültesi Sosyal Bilimler Dergisi 18, no. 32 (2017): 150-153.

${ }^{70}$ Powers, Studies in Qur'àn and Hadìth, 53, 210-211.

${ }^{71}$ Powers, 210. 
istri dikhawatirkan tidak mendapatkan apa-apa untuk menjamin hidupnya karena ia belum menerima mahar. ${ }^{72}$

Di samping reinterpretasi QS. 4: 12a dalam kasus seperti itu, Powers juga melakukan reinterpretasi QS.4: 12b (bab 1) yang mirip dengan actio ad supplendam legitimam, suatu reformasi hukum Justinian yang lain. ${ }^{73}$ Powers lebih berpegang pada teks al-Qur'an yang ditafsir ulang sebagai bukti historis utama klaimnya itu dibanding kesulitan yang dihadapinya bahwa meski secara historis hukum Justinian itu bisa masuk masuk ke Hijaz lewat propinsi-propinsi Byzantium di Timur Dekat, tetap menyisakan probabilitas dalam analisis kesejarahan tentang keterpengaruhan itu atau sebuah kebetulan. Kaum muslimin tentu menyebutnya sebuah kebetulan. Tapi, Powers dengan "logika" kesejarahannya, tentu saja, akan mempertahankan probabilitas itu. Powers mengatakan,

Although it is unlikely that Mubammad or any his followers were directly familiar with Roman law, it is possible that Justinian's reforms found theor way into the Hijaz by way of the Byzantine provinces in the Near East. Leaving aside the question of transmission, let us assume, for the sake of argument, that Q. 4:21a, like Novella 53: 6, was originally intended to apply in the case of unendowned husbands and wives and that, during the lifetime of Mubammad, inheritance upon intestacy was restricted to blood relatives of deceased. Is there any evidence in the Islamic sources that would tend to support this hypothesis, and does this bypothesis make better sense of the data than does the traditional interpretation of Q. 4:12a?74 (Meskipun tidak mungkin bahwa Muhammad atau para pengikutnya telah akrab dengan hukum Romawi, tetapi mungkin reformasi Justinian menemukan jalan masuk ke Hijaz lewat provinsi-provinsi Bizantium di Timur Dekat. Dengan mengesampingkan persoalan tentang transmisi, mari kita asumsikan, seperti Novella 53: 6, yang sejatinya dimaksudkan untuk diterapkan pada kasus suami dan istri-istri yang mendapatkan mahar dan bahwa selama masa hidup Muhammad, pewarisan model $a b$ intestato dibatasi pada kerabat sedarah almarhum. Apakah ada bukti dalam sumber-sumber Islam yang akan cenderung mendukung hipotesis

${ }^{72}$ Tampaknya, ini hanya asumsi yang dianut oleh Powers. Al-Qur'an telah menentukan mahar sebagai bagian dari rukun nikah, sehingga nikah hanya sah dengan mahar ini. Tidak mungkin bahwa al-Qur an menentukan hubungan kewarisan suami-istri itu atas dasar jika istri tidak mendapatkan mahar.

${ }^{73}$ Powers, Studies in Qur'ān and Hadīth, 54-56.

${ }^{74}$ Powers, 78. 
ini, dan apakah hipotesis ini akan membuat makna lebih baik pada data itu daripada yang dilakukan penafsiran tradisional terhadap Q. 4: 12a itu?).

Dengan kutipan di atas, jelas bahwa legislasi al-Qur an dipengaruhi oleh hukum Romawi melalui Novella 53: 6 tersebut yang menyebutkan bahwa suami dan istri yang mendapat mahar tetapi saling mewarisi. Sebelumnya, Powers mengajukan hipotesis bahwa ayat di atas sebenarnya menjelaskan bahwa kewarisan adalah dasar kekerabatan (hubungan darah), sehingga suamiistri, di mana istri telah mendapat mahar, dalam keadaan normal tidak mendapat warisan. ${ }^{75}$ Dari sini, juga tampak bahwa Powers tidak mencurigai adanya keterpengaruhan al-Qur'an dengan hukum Romawi, melainkan ia manruh kecurigaan bahwa pengaruh hukum itu ada pada kaum muslimin generasi awal. Hal ini menandai pergeseran analisis keterpengaruhan dari semula terhadap al-Qur`an sebagaimana dilontarkan oleh John Wansbough.

\section{Kajian al-Qur an Powers: Antara Dominasi Barat dan Inferioritas Timur}

Dari keseluruhan uraian yang dikemukakannya, ia ingin membuktikan bahwa di samping untuk membantah tesis Joseph Schacht, target utama dan pertamanya adalah koreksi terhadap penafsiran kaum muslimin terhadap beberapa ayat tentang waris. Sekalipun ia berhati-hati agar temuannya tidak disalahpahami sebagai menghina Nabi Muhammad, namun kritiknya terhadap kaum muslimin cukup tajam:

First, I argue that the Muslim community is not in possession of the original reading and understanding of several Qur'anic verses and prophetic hadith or of system of inheritance recieved by Muhammad. To put it differently, I maintain that, in the years following the Prophet's death, certain people manipulated the text of the Qur'an in a effort to alter the significance of the verses in question. ${ }^{76}$

(Pertama, saya berpendapat bahwa masyarakat muslim saat ini sebenarnya tidak memiliki pembacaan dan pemahaman yang tepat atas beberapa ayat al-Qur an dan hadits atau atas sistem waris yang diterima oleh Muhammad. Untuk membuktikannya, saya berpendirian bahwa sesudah wafatnya Nabi, beberapa orang tertentu telah memanipulasi teks

\footnotetext{
${ }^{75}$ Powers, 74-75.

${ }^{76}$ Powers, Studies in Qur'ān and Hadìth, xii.
} 
al-Qur`an dalam upaya untuk mengubah makna ayat-ayat yang terkait dengan waris).

Pernyataan ini sama dengan pernyataan bahwa kaum muslimin tidak memiliki pemahaman yang benar tentang kitab suci mereka sendiri, al-Qur`an. "Saya" (I, Powers) dalam kutipan itu merepresentasi "subjek" (Barat) yang mendominasi pembacaannya yang dianggapnya benar dibandingkan "masyarakat Muslim" (Muslim community) sebagai “objek", khususnya generasi awal, baik Sahabat penafsir seperti Ibn 'Abbās, para fuqabā' seperti al-Syāfi''̄ yang melontarkan naskh ayat wasiat dengan ayat waris, dan masyarakat Muslim sekarang yang mengakui ilmu fara $\bar{\imath} i d h$ sebagai media pembagian waris yang sah. Selain bermuatan dominasi, model kajian ini adalah model "kekuasaan intelektual", yaitu cara Barat mendidik Timur. ${ }^{77}$

Cara Powers dalam mendekati isu waris dari pendekatan kritik sastra (literary analysis) tipikal merupakan pendekatan orientalis Yahudi. Prinsip tentang salvation history yang pernah diterapkan oleh orientalis, semisal John Wansbrough, dalam Quranic Studies. Model ini dikembangkan oleh Bultmann dan Neuser dalam kajian terhadap Bibel. Perspektif kajian ini tidak menunjuk pada peristiwa yang seakan benar-benar terjadi.78 Akan tetapi, apa yang sebenarnya terjadi dikesampingkan untuk memberi ruang penafsiran. Berbagai tanggapan dari Muslim dan Barat beragam. ${ }^{79}$ Akan tetapi, yang jelas adalah bahwa konsep bermuatan teologis, karena diyakini adanya andil Tuhan dalam sejarah. ${ }^{80}$

${ }^{77}$ Avant Propost', Dari Seorang Diaspora tentang Politik 'Pasca-Identitas'”, dalam Edward Said, Orientalisme (Yogyakarta: Pustaka Pelajar, 2010), x.

${ }^{78}$ Hamid Fahmy Zarkasyi, “Tradisi Orientalisme dan Framework Studi al-Qur'an," Tsaqafab 7, no. 1 (2011): 17-18.

${ }^{79}$ Lihat kembali Rippin, "Literary Analysis of Qur'ān". Akh Minhaji, "John F. Wansbrough dan Salvation History dalam Kajian Islam," Thaqafiyyat: Jurnal Bahasa, Peradaban dan Informasi Islam 18, no. 2 (2018): 128-145. Fazlur Rahman, Major Themes of the Qur 'ān (Kuala Lumpur: Islamic Book Trust, 1999), 198-201.

${ }^{80}$ Lihat Christian P. Ceroke, "Principles of Salvation History," Marian Studies 16, no. 1 (1965): 29-40. 
Tabel 2:

Pendekatan dan Tipe Kajian David S. Powers

\begin{tabular}{|c|c|c|c|}
\hline No. & Aspek & Posisi David S. Powers & Keterangan \\
\hline 1. & Standar waktu & Abad ke-21 & $\begin{array}{l}\text {-Karya ini terbit pada } \\
2008\end{array}$ \\
\hline 2. & $\begin{array}{l}\text { Paradigma/posisi } \\
\text { terhadap teks }\end{array}$ & $\begin{array}{l}\text { Di depan teks } \\
\text { (before/ in front of text) }\end{array}$ & $\begin{array}{l}\text {-Tidak mempersoalkan } \\
\text { otentisitas, bahkan } \\
\text { menguatkan peran al- } \\
\text { Qur`an dalam proses } \\
\text { legislasi Islam } \\
\text {-Fokus pada reinter- } \\
\text { pretasi teks }\end{array}$ \\
\hline 3. & Sumber & $\begin{array}{l}\text {-Amerika Serikat, } \\
\text { Universitas Cornell, } \\
\text {-Latar belakang Yahudi }\end{array}$ & \\
\hline 4. & Pendekatan & $\begin{array}{l}\text {-Kritik literer } \\
\text {-Kritik sejarah } \\
\text {-Analisis keterpengaruhan } \\
\text { Muslim generasi awal dalam } \\
\text { menafsirkan al-Qur`an de- } \\
\text { ngan hukum Romawi } \\
\text {-Hermeneutis }\end{array}$ & \\
\hline 5. & $\begin{array}{l}\text { Ciri penggambaran } \\
\text { objek yang dikaji }\end{array}$ & $\begin{array}{l}\text {-Kaum muslimin tidak } \\
\text { memiliki pemahaman yang } \\
\text { baik terhadap kitab suci } \\
\text { mereka sendiri }\end{array}$ & $\begin{array}{l}\text { Ada pergeseran dari } \\
\text { kritik terhadap Islam } \\
\text { (sumber: al-Qur`an) ke } \\
\text { masyarakat muslim }\end{array}$ \\
\hline 6. & Agenda & $\begin{array}{l}\text {-Stereotyp terhadap Muslim } \\
\text { sebagai tidak intelektual } \\
\text { (terbelakang), termasuk } \\
\text { dalam memahami al- } \\
\text { Qur`an sendiri } \\
\text {-Inferior }\end{array}$ & \\
\hline
\end{tabular}

\section{Simpulan}

Pertama, dari segi pendekatan, kajian Powers terhadap perubahan hukum awal Islam tentang waris menjadi 'ilm al-farā $i d h$ menerapkan pendekatan sintesis, yaitu (1) kritik sastra (literary criticism) terhadap pemapanan ilmu ini melalui telaah ulang atas penafsiran, mengritik pembacaan (qirā'at), dan analisis linguistik, (2) kritik sejarah atas menggunakan data sejarah untuk melihat berbagai klaim pembakuan ilmu dengan sarana-sarana analisis ini, seperti konteks historis-politis suksesi pada masa awal Islam. 
Dalam konteks tipologi kajian orientalis, kajian Powers merepresentasikan trend revisionis yang meski tidak menggugat otentisitas, dan malah menguatkan peran al-Qur`an dalam proses legislasi hukum waris Islam, tapi dengan model perspektif salvation history, tidak memercayai sumbersumber tradisional dalam Islam. Perubahan hukum waris itu kemudian dikritisi dasar-dasarnya untuk menemukan hukum awalnya. Jadi, Powers menempatkan teks di depan (before/ in front of text).

Dari perspektif studi post-kolonial, klaim Powers bahwa kaum muslimin tidak memiliki pemahaman yang benar tentang kitab suci mereka sendiri, al-Qur an, tentu secara ideologis muncul dari relasi pengetahuan-kuasa (knowledge and power), khususnya "kuasa intelektual". Powers dalam konteks kuasa ini ingin menempatkan Barat, sebagai non-muslim, bahkan sebagai lebih terpelajar dan lebih superior dalam memahami kitab suci al-Qur`an miliki umat Islam. Skema superior-inferior (Barat-Islam) menjadi ideologi yang invest the body (menyusup dalam tubuh) yang secara sadar atau tidak sadar menggerakkan dan mengerahkan kajian "ilmiah" itu.

\section{Daftar Pustaka}

Adams, Charles J. "Islamic Religious Tradition", dalam Leonard Binder (ed.), The Study of the Middle East: Research and Scholarship in the Humanities and the Social Sciences. New York: John Wiley \& Sons Inc., 1976.

'Amiri, 'Abdallah M. al-Husayn al-. "At-Thüfi's Refutation of Traditional Muslim Juristic Sources of Law and His View on the Priority of Regard for Human Welfare as the Highest Legal Sources or Principle." Canada: McGill University, 1993.

Arkoun, Mohammed. Lectures du Qoran, terjemah Machasin dengan judul Berbagai Pembacaan Quran. Jakarta: INIS, 1997.

Azra, Azyumardi, dan Idris Thaha. Historiografi Islam Kontemporer: Wacana, Aktualitas, dan Aktor Sejarah. Jakarta: Gramedia Pustaka Utama, 2002.

Basir, Abdul. Dekonstruksi Sumber Hukum Islam: Pemikiran Hukum Najm ad-Dīn Thufi. Jakarta: Penerbit Gaya Media Pratama, 2004.

Baso, Ahmad. Islam pascakolonial: perselingkuhan agama, kolonialisme, dan liberalisme. Bandung: Mizan, 2005.

Bonner, Michael. "Reviews." International Journal of Middle East Studies 26, no. 2 (1994): 343. 
"CD-ROM Mawsū'at al-hadīts asy-syarīf." Syarikat al-barāmij al-Islāmiyyah aldawliyyah [Global Islamic Sofware Company], 2000.

Ceroke, Christian P. "Principles of Salvation History." Marian Studies 16, no. 1 (1965): 29-40.

Ernst, Carl W., dan Richard C. Martin. Introduction: Toward a Post-Orientalist Approach to Islamic Religious Studies dalam Rethinking Islamic Studies, ed. Carl W. Ernst dan Richard C. Martin. Columbia: University of South Caroline Press, 2010.

Hasan, Ahmed. The Early Development of Islamic Jurisprudence. India: Adam Publishers \& Distributors, 1994.

Hidayati, Niswatul. "Rekontruksi Hukum Waris Islam: Makna Kalalah David S. Power." Muslim Heritage 2, no. 1 (2017): 177-198.

Juynboll, Gautier H.A. Muslim tradition: studies in chronology, provenance, and authorship of early hadith. Cambridge: Cambridge University Press, 1983.

Kerboua, Salim. "From Orientalism to neo-Orientalism: Early and contemporary constructions of Islam and the Muslim world." Intellectual Discourse 24, no. 1 (2016): 21.

Khan, Mohammad Mustafa Ali. Islamic Law of Inheritance: a New Approach. New Delhi: Kitab Bhavan, 1989.

Mahyuddin, Anas. Fazlurrahman Terj. Anas Mahyuddin Membuka Pintu Ijtibad. Bandung: Penerbit Pustaka, 1884.

Minhaji, Akh. "John F. Wansbrough dan Salvation History dalam Kajian Islam." Thaqafiyyat: Jurnal Bahasa, Peradaban dan Informasi Islam 18, no. 2 (2018): 128-145.

Powers, David S. Peralihan Kekayaan dan Politik Kekuasaan. Yogyakarta: LKiS, 2001.

- Studies in Qur'àn and Hadith: The Transformation of the Islamic Law of Inheritance. Berkeley: University of California Press, 1986.

Propost', Avant. Dari Seorang Diaspora tentang Politik 'Pasca-Identitas'”, dalam Edward Said, Orientalisme. Yogyakarta: Pustaka Pelajar, 2010.

Qadafy, M. Z. "Kontroversi Islam Revisionis: David S. Powers, Zayd Ibn rithah dan Tertutupnya Pintu Kenabian." Nun 4, no. 1 (2018): 45-81.

Rahman, Fazlur. Islamic Methodology in History. New Delhi: Adam Publishers \& Distributors, 1994.

—. Major Themes of the Qur ān. Kuala Lumpur: Islamic Book Trust, 1999. 
Rahman, Yusuf. “Tren Kajian Al-Qur'an Di Dunia Barat.” Jurnal Studia Insania 1, no. 1 (2013): 1-8.

Reynolds, Gabriel Said. "Introduction: Qur'anic studies and its controversies." Dalam The Qur'an in its Historical Context, 17-42. London; New York: Routledge, 2007.

Rippin, Andrew. Literary Analysis of Qur'ān, Tafsìr, and Sìra: The Methodologies of John Wansbrough", dalam Approaches to Islam in Religious Studies, ed. Richard C. Martin. Tucson: The University of Arizona Press, 1985.

Ritzer, George, dan Douglas J. Goodman. Modern Sociological Theory terj. Alimandan. Jakarta: Kencana, 2003.

Schacht, Joseph. An introduction to Islamic Law. Repr. Oxford: Clarendon Press, 1984.

Tekdemir, Hande. "Critical Approaches to Edward Said's Orientalism." Social Sciences Review of the Faculty of Sciences \& Letters University of Uludag/Fen Edebiyat Fakuiltesi Sosyal Bilimler Dergisi 18, no. 32 (2017).

Tirmidzī, Sunan at-. "Kitāb al-Farā idh 'an Rasūl Allāh, hadīts nomor 2017," t.t.

Wibowo, Safrudin Edi. "Kritik Sejarah dan Literasi terhadap Hukum Waris Islam dalam Pandangan David S. Powers." Jurnal Islamica 4, no. 2 (2013): 306-18.

Wright, Ian. "History, Hermeneutics, Deconstruction", dalam Jeremy Hawthorn (ed.), Criticism and Critical Theory. Baltimore: Edward Arnold, 1984.

Ya'kub, Ali Mustafa. Kodifikasi Hadis Nabi. Jakarta: Pustaka Firdaus, 1994.

Zadeh, Travis. "Quranic studies and the literary turn." Journal of American Oriental Society 135, no. 2 (2015): 329-342.

Zarkasyi, Hamid Fahmy. "Tradisi Orientalisme dan Framework Studi alQur'an." Tsaqafab 7, no. 1 (2011): 1-30.

Zhamī, Muhammad Mushthafā al-A'. "Dirāsah fĩ al-Hadīts an-Nabaw̄ìy wa Tāñ̄kh Tadwūnihb.” Beirut: Dār al-Fikr, 1973. 